Article

\title{
Spatial Relations between the Standards of Living and the Financial Capacity of Polish District-Level Local Government
}

\author{
Mariusz Malinowski * (D) and Joanna Smoluk-Sikorska $\mathbb{D}$ \\ Department of Economics, Faculty of Economics and Social Sciences, Poznań University of Life Sciences, \\ 60637 Poznan, Poland; smoluk@up.poznan.pl \\ * Correspondence: mariusz.malinowski@up.poznan.pl
}

Received: 20 January 2020; Accepted: 25 February 2020; Published: 28 February 2020

check for updates

\begin{abstract}
The objective of the presented article is the identification of spatial relations between the inhabitants' standards of living and the districts' financial capacity basing on data for 2017. The investigation comprised all of the 380 Polish districts. In regard to the multidimensionality of economic occurrences analyzed, the TOPSIS (The Technique for Order of Preference by Similarity to Ideal Solution) approach to measure the inhabitants' standards of living and the financial ability of districts was applied in the research. A spatial autocorrelation analysis between the taxonomic (synthetic) indexes was performed using local and global Moran's I statistics in order to determine the districts' clusters, demonstrating a comparable degree of occurrences analyzed. A spatial regression analysis was conducted to find the strength of spatial relations between the taxonomic index of the standards of living and the districts' financial ability. Diagnostic variables were chosen according to substantive, statistical and formal criteria. The outcomes of the spatial regression analysis allowed it to be concluded that about $1 \%$ increase of the taxonomic indicator of the districts' financial ability is reflected in about $0.4 \%$ growth of the taxonomic index of the standards of living of the inhabitants of different districts (other things being equal). The results of analyses can be applied indirectly by a number of stakeholders, e.g., local authorities responsible for local and regional development, when creating the development strategies at local government unit (LGU) level. The knowledge on spatial development structures can enhance the formation of the strategic management process (for instance, redefining the objectives and tasks set out in local strategies; restructuring the expenditure to meet the local population's needs).
\end{abstract}

Keywords: spatial analysis; local government finance; standards of living

\section{Introduction}

The financial ability of local government units may be assumed to play a special role in driving socioeconomic development at regional level. An adequate amount of financial resources is necessary in order for local government units to achieve the specific goals and accomplish the assignments of the central government (comprised of ensuring the appropriate level of public services and supporting the population while facing tough living situations). The main focus of regional and local sustainable development efforts is on the regions' population, and therefore improvements in the population's standards and quality of living are an important proxy for regional (or local) sustainable development. Indeed, sustainable development is an economic doctrine which assumes that the population's living standards should match the current level of human development. In this context, note that the main objective of the Long-term National Development Strategy: Poland 2030. The third wave of modernity, which sets out the key trends and scenarios of socioeconomic development, is "to increase the quality 
of life of the Polish population, estimated both with qualitative indicators and with the value and growth rate of Polish GDP" [1].

In addition to being the subject of numerous scientific papers, the standards of living are addressed at different aggregation levels (regional, national, international) in expert assessments prepared for public institutions (including Diagnoza społeczna 2015 warunki i jakość życia Polaków [2]; How's Life? 2015 Measuring Well-being [3]; and Living Conditions in the European Union [4], a report by the European Commission). Although this issue has been discussed for many years, there is disagreement on the operationalization of variables related to the standards of living. This is a multifaceted phenomenon which sparks a lively public debate (including dedicated seminars and scientific conferences) and is subject to numerous scientific research projects. Nevertheless, both the quantification of the standards of living and the identification of factors that contribute to it, are problems yet to be fully solved. The standards of living are a highly complex and heterogeneous issue, and therefore a great variety of statistical tools are needed to address it. The difficulty lies in selecting and weighing the sub-variables, and in finding relevant measuring methods and methods for the identification of relations between the categories considered. Particular academics give special meaning to stimulating (and inhibiting) determinants, somewhat less importance is put to spatial interactions between these categories (the geographic areas are studied as isolated objects). It seems to be very significant, because, the standards of living in individual local government units (LGUs) change together with the political, legal, economic or social and cultural surroundings. Moreover, the standards of living in one territorial unit might influence the level observed in a close or bordering one. Thus, studies including spatial regression are becoming more and more vital, since the researchers include the spatial relations between objects (LGUs) in the analyses. Avoiding spatial relations in the design of spatial models can result in the opposite influence on the estimation quality of the structural parameters of the models.

The main article's objective is the determination of the relations between synthetic measures of inhabitants' standard of living and the financial abilities of LGUs in the Polish districts including spatial interactions between phenomena analyzed. The analysis of the socio-economic occurrences should involve the influence of the spatial structure of the objects (for instance, districts) on the considered occurrence, since the spatial structure is often an outcome of the impacts of particular factors, mostly of historical, cultural or sociological character. In these kinds of analyses, it is necessary to compare a number of objects studied which are described with a wide mix of variables. It means that it is difficult to express the development level of a particular occurrence with the use of one measurable feature. This contributes to the fact that multidimensional statistical analysis methods based on synthetic measures of development were employed. The application of the synthetic measures, which substitute the description of the objects using a number of variables, with the description using one aggregated value, enabled the measurement of the multidimensional occurrence like inhabitants' standard of living (and a districts' financial ability). It also allowed for linear classifying of the investigated objects. In order to identify the development level of the investigated phenomena, the TOPSIS method was applied. To determine the depth of spatial relations between analyzed districts in the area of standards of living and financial abilities, the spatial autocorrelation basing on local and global Moran's statistics was used. Regarding the identification of the spatial effects, the empirical analysis of the relations between synthetic measures of standard of living and districts' financial ability was performed using spatial regression models (for 2017). The investigation covered 380 districts (including 66 urban districts). All statistical data used in this study were obtained from the publicly available Local Data Bank of the Central Statistical Office [5].

\section{Inhabitants' Standards of Living and Districts' Financial Ability}

Though widely used in day-to-day communication, standards of living is a term which, due to its multifaceted nature, does not have a single, widely accepted definition. It is largely based on the theory of needs. The standards of living can be more or less an umbrella term (see Table 1 [6-9]) which largely results from the fact that it is subject to research in many scientific disciplines, including 
sociology, philosophy, economics, physiology or psychology. Hence, on the one hand, there is a broad interdisciplinary perspective spanning multiple problems and methodologies and, on the other, the operationalization of this research category is also problematic.

A need is defined as a condition where an individual experiences a lack of something; social needs, in turn, are needs which, in order to be met, require the existence and operation of different social institutions established to pursue defined objectives. Characteristically, needs change over time; that pattern is true for superior (luxury) needs much more than for basic needs (e.g., food, housing) [6] (p. 101).

L. Zienkowski proposed a classification of needs, in which degree of satisfaction is indicative of wealth, often equated with the standards of living [10]:

- needs which are met by accessing natural goods and the natural environment,

- needs related to the process of working (working conditions),

- needs which are met through the general consumption of physical goods and intangible services by households and through the acquisition of tangible goods and intangible assets,

- mental needs related to those listed above.

Table 1. Categories of human needs.

\begin{tabular}{|c|c|}
\hline $\begin{array}{l}\text { Luszniewicz } \\
\text { (1982) [6] }\end{array}$ & $\begin{array}{l}\text { 1. Food; } 2 \text {. Housing; 3. Healthcare; } 4 \text {. Education; } 5 \text {. Leisure; } 6 \text {. Social security; 7. Provision } \\
\text { of physical goods. }\end{array}$ \\
\hline $\begin{array}{l}\text { Krawczyk et al. } \\
\quad(1990)[6]\end{array}$ & $\begin{array}{l}\text { 1. Food; } 2 \text {. Housing; } 3 \text {. Health; } 4 \text {. Education; } 5 \text {. Leisure; } 6 \text {. Social security; } 7 \text {. Financial } \\
\text { security; } 8 \text {. Natural environment. }\end{array}$ \\
\hline Max-Neef (1991) & 1. Subsistence; 2. Protection; 3. Affection, 4. Understanding; 5. Participation; 6. Idleness; \\
\hline$[7,8]$ & 7. Creation; 8.Identity; 9. Freedom. \\
\hline Słaby (1994) [6] & $\begin{array}{l}\text { 1. Biological condition (food, housing, health, natural environment, leisure); } 2 \text {. Professional } \\
\text { status (having a job, working time, wages); } 3 \text {. Financial condition (savings, prices, } \\
\text { durables); } 4 \text {. Educational status (education for children, youth and adults; culture and } \\
\text { arts); } 5 \text {. Social status (social security; income equality, social pathologies; family and social } \\
\text { ties, politics). }\end{array}$ \\
\hline Śmiłowska & 1. Personal income of the population; 2 . Environmental degradation; 3 . Health level; \\
\hline (1995) [6] & 4. Working conditions; 5 . Social relationships and public security. \\
\hline Central & 1. Income; 2. Household expenditure; 3 . Food consumption; 4. Housing conditions; \\
\hline $\begin{array}{l}\text { Statistical Office } \\
\quad(2004)[6]\end{array}$ & $\begin{array}{l}\text { 5. Availability of durables in households; } 6 \text {. Healthcare and social assistance; } 7 \text {. Education; } \\
\text { 8. Culture and leisure. } \\
\text { 1. Physiological Needs; } 2 \text {. Physical Health and Safety Needs; } 3 \text {. Leisure and Aesthetic }\end{array}$ \\
\hline Ding, Jiang, & Needs; 4. Social, Self-Worth, and Self-Esteem Needs; 5 . Finances, Possessions, and Job \\
\hline Riloff (2018) [8] & $\begin{array}{l}\text { Needs; } 6 . \text { Cognition and Education Needs; } 7 \text {. Freedom of Movement and } \\
\text { Accessibility Needs. }\end{array}$ \\
\hline
\end{tabular}

The degree to which the population's needs are met is assessed as part of intertwined fields of research, such as standards of living, quality of life, and welfare.

In 1954, a UN expert committee defined the population's standards of living as "the overall actual living conditions of humans and the extent to which their physical and cultural needs are met by the flow of goods and services, whether paid or derived from social funds" (after: [11]). That definition gave grounds for a number of other ones created later on. C. Bywalec and L. Rudnicki describe the standards of living as the level of satisfaction of needs as a result of consuming man- made physical and intangible goods [12]. J. Piasny claims that "the standards of living is a term which means, in a general sense, that the quality of living conditions determined by the degree to which major needs (living a settled, comfortable and enjoyable life) are met. In this approach, it is the synonym of living conditions in the broadest sense" [13] (p. 73). Quite an extensive definition of the standards of living was proposed by J. Berbeka. According to her, "the standards of living mean the condition and availability of goods, services and conditions, based on which an individual (community member) can address his/her physical and spiritual needs; and the extent to which such goods, services and 
conditions are used" [14] (p. 13). M.E. Hansen and F. Grubb define the standards of living as the utility or happiness derived while consuming. In that sense, consumption is broadly understood as any other good, activity or status which individuals can acquire/attain [15]. In turn, S. Kalinowki [16] (pp. 18-19) defines standards of living as the "system of synthetic indicators resulting from the level of wealth manifested in how the physical and intangible needs are met and, as a consequence, in the economic capability, commitments and aspirations of individuals."

In the nomenclature used by One Global Economy, the standards of living are primarily determined by three categories [17]: income (variation in annual income, savings, employment and career; entrepreneurship); education (graduation from a secondary school, acceptance into a tertiary program); health (availability of a healthcare system, disease management programs, preventive medicine, including prenatal care, sanitation services, vaccination). According to the Organization for Security and Cooperation in Europe (OSCE), an adequate standard of living [18] (p. 126):

- Suggests that everybody will enjoy indispensable subsistence rights: sufficient food and nutrition, clothing, housing, and the necessary conditions of care when needed.

- In material terms, a sufficient standard of living means living above the poverty line of the society concerned, that is, the ability to purchase a minimum standard of nutrition and ability to meet the cost of taking part in the everyday life of society.

- "Sufficient" is context specific-it will be determined by dominant social, economic, cultural, climatic, ecological, and other conditions.

Although studies are abundant, no single, widely accepted definition of "standards of living" has been developed yet. As a consequence, that term tends to be equated with the quality of life (or with other categories such as living conditions or welfare). Note, however, that most authors agree that these categories should be considered separately. In the Polish literature, the definitions of "standards of living" and "quality of life" were extensively reviewed by A. Zeliaś [11] (pp. 13-18). Table 2 presents the selected definitions.

When analyzing the above definitions, it may be concluded that the "standards of living" usually relate to the extent to which physical and physiological needs are met, while the "quality of life" refers to the valuation of the different aspects of living. Based on a literature review, S.L.T. McGregor and E.B. Goldsmith provide a synthetic explanation of differences between the quality and the standards of living (and wealth). They believe that the "standard of living reflects actual reality; quality of life is one's perception of and satisfaction with that reality; and well-being is comprised of indicators of this reality (economic, social, physical, emotional and spiritual) with special attention to the underprivileged via family/social welfare" [19].

Undeniably, a part of human needs may be satisfied individually (privately) only. Nevertheless, particular needs are satisfied using public resources (for instance, the need for security and order in the surrounding), as a consequence of direct or indirect actions of central or local governments (based on the dispersal of competences and the decentralization of public finance which consists in that local government units are legally conferred with the authority to access and allocate financial resources by the central government). This is because the living environment of the local population is their local social system (where individuals spend most of their time).

Local government is "a form of a decentralized public administration system which performs, on its own and at its own responsibility, tasks assigned under relevant acts. Local government units are subject to rules of law which consider them as separate legal entities in the country's organizational

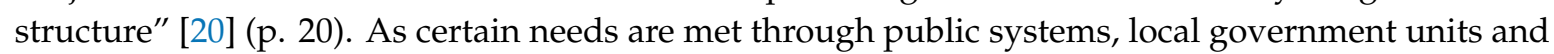
other authorities are required to take measures focused on the commitment of expenditure and on collecting funds that are necessary to cover the expenditure. As it comes to local government finance, it can be considered in broad or narrow terms. In a broader sense, it means the processes of collecting and spending public funds of local government units. In a narrower sense, local government finance can be divided into local and regional finance. Regional finance is about collecting and spending 
public financial resources by regional-level government units, whereas local finance is the part of local government finance which involves collecting and spending public financial resources by sub-regional government units. The objective of local government finance is to collect enough financial resources to address the ever-growing demand for public and social services delivered by the local government sub-sector [21] (pp. 49-50). The decentralization of public finance contributes to, without limitation [22] (p. 210):

- a more adequate allocation of funds thanks to a better identification of needs of the local community,

- a more efficient control over how public funds are spent, the decision-maker being less anonymous,

- a greater efficiency of government operations, as the central authorities delegate some of their powers to the local level.

Table 2. Standards of living and inhabitants' quality of life.

\begin{tabular}{|c|c|c|c|}
\hline \multicolumn{2}{|r|}{ Standards of Living } & \multicolumn{2}{|r|}{ Quality of Life } \\
\hline Author & Definition & Author & Definition \\
\hline $\begin{array}{l}\text { Z. Żekoński } \\
\text { (1974) [11] }\end{array}$ & $\begin{array}{l}\text { Overall conditions of living of a } \\
\text { society, social and professional } \\
\text { group, household or individual, } \\
\text { primarily reflected by the facilities } \\
\text { that underpin the process of meeting } \\
\text { individual and collective needs. }\end{array}$ & $\begin{array}{c}\text { T. Słaby (1990) } \\
\text { [11] }\end{array}$ & $\begin{array}{l}\text { All those aspects of human life that } \\
\text { are related to an individual's } \\
\text { existence, being someone and } \\
\text { experiencing different emotions } \\
\text { resulting, for instance, from having } \\
\text { a family, friends etc. }\end{array}$ \\
\hline $\begin{array}{l}\text { A. Luszniewicz } \\
\text { (1982) [11] }\end{array}$ & $\begin{array}{l}\text { The degree to which physical and } \\
\text { cultural needs of households are } \\
\text { met (in the sense of securing) } \\
\text { through flows of paid goods and } \\
\text { services and flows of collective } \\
\text { consumption funds. }\end{array}$ & $\begin{array}{l}\text { C. Bywalec } \\
\text { (1991) [11] }\end{array}$ & $\begin{array}{l}\text { The degree to which an individual } \\
\text { (a society) is satisfied with his/her } \\
\text { (their) overall existence. }\end{array}$ \\
\hline $\begin{array}{c}\text { T. Słaby (1990) } \\
\text { [11] }\end{array}$ & $\begin{array}{l}\text { The degree to which physical needs, } \\
\text { related to basic (physiological) } \\
\text { human needs, are met. }\end{array}$ & $\begin{array}{c}\text { W. Sęk (1993) } \\
\text { [11] }\end{array}$ & $\begin{array}{l}\text { In an objective approach, quality of } \\
\text { life means all conditions of human } \\
\text { living; objectively assessed human } \\
\text { attributes related to an individual's } \\
\text { standards of living and social status. } \\
\text { Conversely, in the subjective } \\
\text { approach, the standards of living } \\
\text { are the result of internal valuation } \\
\text { processes of different parts of life } \\
\text { and of one's life as a whole. }\end{array}$ \\
\hline $\begin{array}{l}\text { C. Bywalec, } \\
\text { S. Wydymus } \\
(1992)[11]\end{array}$ & $\begin{array}{l}\text { The degree of meeting the } \\
\text { population's needs as a result of } \\
\text { consuming man-made physical and } \\
\text { intangible goods and leveraging the } \\
\text { values of the natural and social } \\
\text { environment. }\end{array}$ & $\begin{array}{l}\text { M. Adamiec, } \\
\text { K. Popiołek } \\
(1993)[11]\end{array}$ & $\begin{array}{l}\text { Two aspects of quality of life: } \\
\text { internal and external quality. The } \\
\text { external qualify of life conditions } \\
\text { and provides a foundation for the } \\
\text { internal quality and provides the } \\
\text { individual with better opportunities } \\
\text { to improve his/her internal quality } \\
\text { of life. The internal quality is a } \\
\text { yardstick of the development level } \\
\text { of the society and the world: the } \\
\text { place where people live their lives. }\end{array}$ \\
\hline
\end{tabular}

The decentralization of public finance and the separation (dispersal) of competences related to addressing the population's collective needs between central and local authorities depends on a country's history (in Poland, local government developed in the 1800s as part of political and economic systems of the partitioning powers, but its origins date back to Middle Ages). Table 3 presents selected own tasks of Polish local government units at different levels (performed by themselves, at their discretion, without unlawful interference of central authorities) [23-25]. In Poland, local government has been operating since 27 May 1990 (the day the Local Government Act of 8 March 1990 [23] entered into force). Initially, it was only a one-level local government system with urban, rural and urban-rural municipalities. District-level and voivodeship-level local government was established in 1999 in 
relation to the reform of the administrative division. Today, Poland has 2478 municipal government units, 380 district government units, and 16 voivodeship government units.

Table 3. Selected own tasks of Polish municipalities, districts and voivodeships.

\begin{tabular}{|c|c|c|}
\hline Tasks of Municipalities & Tasks of Districts & Tasks of Voivodeships \\
\hline $\begin{array}{l}\text { Matters related to, without limitation: } \\
\text { - } \quad \text { orderly development; real estate } \\
\text { management; nature and } \\
\text { environmental protection; } \\
\text { water management; } \\
\text { municipal roads, streets, bridges } \\
\text { and squares; traffic organization } \\
\text { of roads; } \\
\text { - } \quad \text { waterworks and water supply; } \\
\text { sewage system; municipal } \\
\text { wastewater removal and } \\
\text { treatment; electricity, heat and } \\
\text { gas supply; } \\
\text { telecommunications activity; } \\
\text { - } \quad \text { local public transport; } \\
\text { healthcare; } \\
\text { - } \quad \text { social assistance; } \\
\text { - } \quad \text { municipal residential housing; } \\
\text { - } \quad \text { public education; } \\
\text { culture; } \\
\text { - }\end{array}$ & $\begin{array}{ll}\begin{array}{l}\text { Supra-municipal public tasks in the area } \\
\text { of: }\end{array} & \\
- & \text { public education; } \\
- & \text { protecting and promoting health; } \\
- & \text { social assistance; } \\
- & \text { family policies; } \\
- & \text { support for disabled people; } \\
- & \text { public transportation and roads; } \\
- & \text { culture and maintenance of } \\
& \text { cultural goods; } \\
- & \text { physical culture and tourism; } \\
- & \text { real estate management; } \\
- & \text { water management; } \\
- & \text { nature and } \\
\text { environmental protection; } \\
-\quad \text { public order and citizens' security; } \\
\text { fire protection; } \\
-\quad \text { fighting unemployment and } \\
\text { stimulating the local labor market; } \\
-\quad \text { consumer rights protection; } \\
-\quad \text { defense; }\end{array}$ & $\begin{array}{l}\text { Voivodeship local government performs } \\
\text { voivodeship-level tasks, including } \\
\text { without limitation: } \\
\text { - } \quad \text { public education, including } \\
\text { higher education; } \\
\text { - } \quad \text { protecting and promoting health; } \\
\text { - } \quad \text { culture; monument protection } \\
\text { and maintenance; } \\
\text { - } \quad \text { social assistance; } \\
\text { - } \quad \text { family support; foster care system; } \\
\text { - } \quad \text { rumily policies; } \\
\text { - } \quad \text { land use management; } \\
\text { - } \quad \text { environmental protection; } \\
\text { - } \quad \text { public transport and roads; } \\
\text { - } \quad \text { physical culture and tourism; } \\
\text { - } \quad \text { consumer rights protection; } \\
\text { - } \quad \text { defense; } \\
\text { - } \quad \text { public security; } \\
\text { - } \quad \text { fighting unemployment and } \\
\text { - } \quad \text { stimulating the local labor market; } \\
\text { telecommunications activity; }\end{array}$ \\
\hline
\end{tabular}

As it can be easily noticed, the statutory task of local government units (especially including municipalities, because they have a broad spectrum of regulatory and coordination instruments) is primarily to take measures designed to develop favorable conditions for improving the living of the local population (cf. [23]).

Obviously, other tasks of (municipal) local government units are to be carried out to (directly and indirectly) address the population's collective needs. Rather than being provided for in applicable regulations, these tasks stem from the very essence of local government and include: identifying local needs; implementing various amenities and facilities; creating the "space for working" (including by supporting the development of business incubators); offering discounts, incentives and subsidies; developing a local education and training system (cf. [26] (p. 214)).

In this context, note that according to the provisions of the Constitution of the Republic of Poland (Article 166, Para. 2) [27], in addition to their own tasks, local government units may carry out public tasks delegated by central administration authorities whenever such a need arises in the country. Delegated tasks are optional (i.e., they can be delegated) and are carried out upon allocation of adequate financial resources.

As M. Tetera rightly points out, the transfer of public tasks to local government units is primarily determined by the efficiency of tasks performed by local governments. This is because small, integrated communities are best placed to understand local needs. Also, they are able to manage the financial resources entrusted to them more economically [28] (p. 54). The beneficiaries of these tasks are local residents (in a direct way, as consumers of public services) as well as economic operators and other organizational units, in a broad sense (including community centers, libraries, social assistance institutions). Obviously, the performance of these tasks (investment implementation standards, frequency of measures taken, service quality) depends not only on the amount of funds available to local government units but also on their physical assets and human capital.

According to S. Owsiak, since today's economy is of a pecuniary nature, an operator (including a local government unit) can engage in an economic activity provided that it has and can dispose of 
financial resources. The financial conditions of running a business always impose limitations on its size, irrespective of whether it is run on a commercial basis or is financed with transferred funds [29].

As a part of the public sector, local government units rely on public funds in carrying out their tasks. Pursuant to the Public Finance Act of 27 August 2009, public funds include [30]: public income; funds derived from the European Union budget; non-repayable funds derived from aid schemes offered by member states of the European Free Trade Association; other non-repayable foreign funds; incomes of the state budget and of LGTs and other public finance sector units', derived from: the sales of securities, privatization of Treasury's assets and of local government assets, repayment of loans and credits granted on public funds, loans and credits obtained, and other financial operations; incomes of the public finance sector units derived from their activity and from other sources.

The socioeconomic (or sustainable) development level of local government units (municipalities, districts, voivodeships) has a direct or indirect influence on the population's standards of living. In turn, a feedback loop exists between the degree of socioeconomic development and the financial capacity of LGUs (Figure 1) [31] (p. 207).

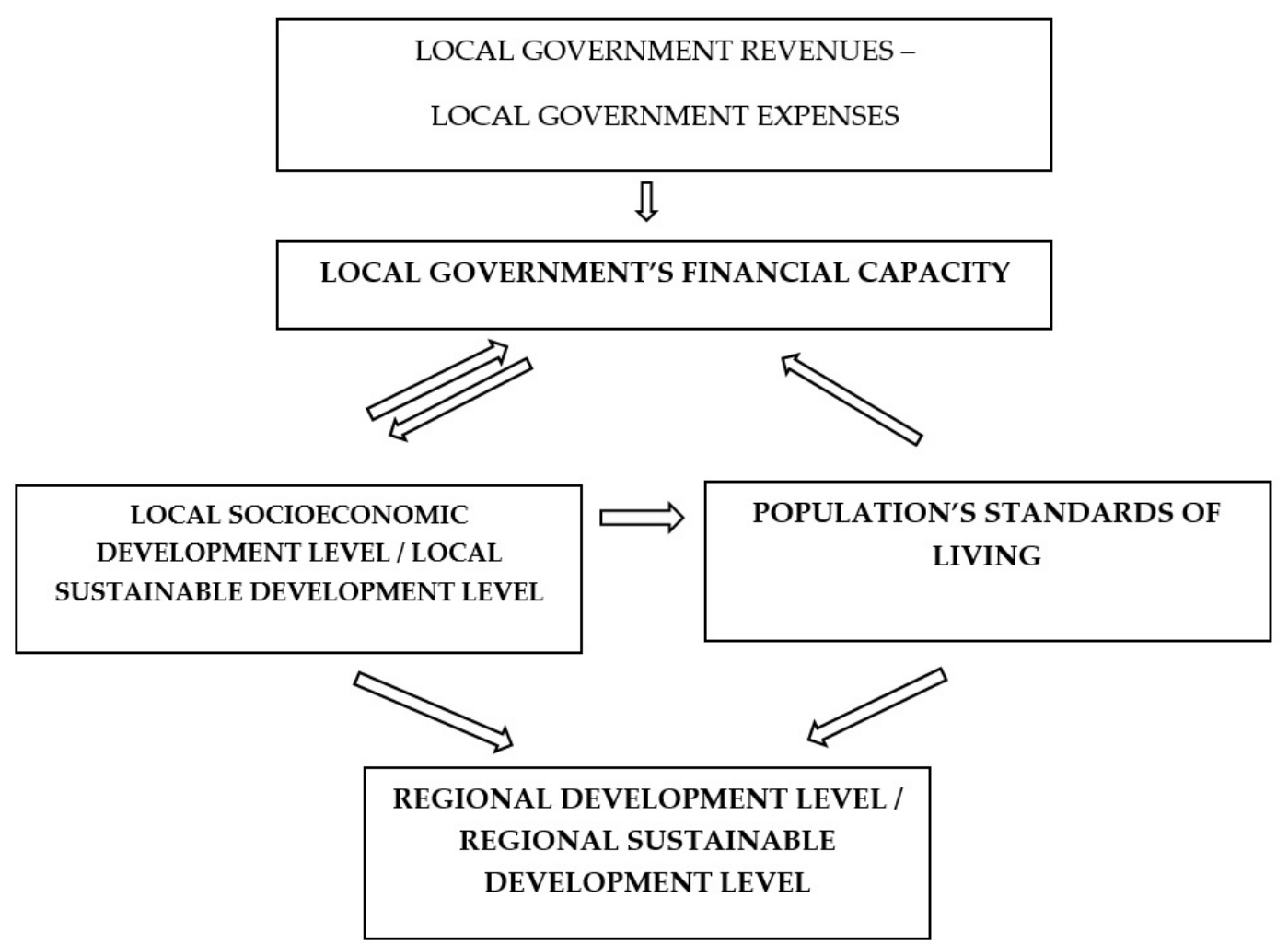

Figure 1. Local government units' financial capacity vs. inhabitants' standards of living.

On the other hand, it seems that higher inhabitants' standards of living could contribute to increasing local government's income (which is due to several reasons, including the fact that LGUs have a share in personal income taxes collected from natural persons living in the unit concerned-for the municipalities, districts and voivodeships that share is $39.34 \%, 10.25 \%$, and $1.60 \%$, respectively [32]). But at the same time, higher standards of living drive higher expectations for investment standards and public service quality (for instance, in the area of culture, education and public order).

The amount of funds available to local government units determines their ability to implement investments that stimulate (socioeconomic or sustainable) development without the need to restrict the performance of their ongoing tasks. The efficiency of local investments (including in the area of building and enhancing the economic and social infrastructure) is very often a determinant for the degree to which both physical and intangible needs of the population are addressed. The Local Government Act 
imposes several duties on the local administration, the initiation, coordination and performance of which is supposed to meet the collective needs of the population. According to Article 7 of the Act, "addressing the collective needs of a community is among the own assignments of a municipality." This specifically includes aspects related to orderly development, healthcare, public education, and culture. Supra-municipal public tasks provided for in the relevant acts are the responsibility of districts [24]. From the perspective of these considerations, particularly important tasks of districts include those related to fighting unemployment and stimulating the local labor market.

\section{Materials and Methods}

Over recent years, the quantification of standards of living has been discussed in many publications. Linear ordering, i.e., the classification of objects by inhabitants' standards of living has been performed at different aggregation levels (local, regional, and international). In this context, note the wide taxonomic analysis of the standards of living of the EU inhabitants performed by A. Zeliaś et al., covering identifying categories of member states that are alike in this area, and the analysis of correspondence used as a comparative analysis tool [11]. Researchers that applied taxonomic methods to measurement of standards of living are: K. Warzecha who compared the standards of living between Poland and EU countries based on the Hellwig's and Ward's method [33]; A. Majka who classified Polish voivodeships [34]; M. Janusz who analyzed the cross-territorial variation in the standards of living between districts of the Warmińsko-Mazurskie voivodeship (based on the Hellwig's method) [35]; and Liang Z., Changdi S. and Liming L. that used the TOPSIS approach to linearly classify the cities in the Guizhou province by standard of living of the local inhabitants [36].

Despite the fact that there are particular articles covering the problem of local government units financing and the inhabitants' standards (or quality) of living (e.g., M. Łapczyński [37], N. Hlepas [38], B. Oleszko-Kurzyna [39], Cárcaba A. et al. [40]) or local development (e.g., J. Dynowska, E. Rudowicz [41], H. Pondel [42]), there is lack of studies of empirical character on spatial interactions between those occurrences.

The study discussed in this paper covered all of the 380 Polish districts, including 66 urban districts (the particularity of urban districts is that in addition to municipal tasks, they are also vested with district-level tasks, see Table 3). In Poland, districts are local government units comprising part of a voivodeship area. They are composed of smaller local government units referred to as municipalities (gmina). In Poland only part of the tasks of local and regional character is realized by government administration agendas (being subject to the Council of Ministers, Prime Minister or particular ministers). A considerable part of the administrative tasks that do not have nationwide significance is realized by the territorial authorities. It is done by local authority bodies that are subject to particular local community (municipalities, districts) or regional (voivodships) and represent their interests. In accordance with the law, the districts realize the public assignments related to the social aid for inhabitants, education, health protection, support for disabled people, public roads and transportation as well as culture. In frames of administrative division, there are 16 voivodships in Poland, that are divided into 380 districts (powiats) covering 2478 municipalities. In turn, the Polish district is the equivalent of the German and Austrian Kreis, or the Czech and Slovak okres In the territory under consideration (as at 31 December 2017), the city of Warsaw (1,764,615 inhabitants) and the Sejny district (20,270 inhabitants) are the first and the last district considering the number of inhabitants. The Białystok district $\left(2975 \mathrm{~km}^{2}\right)$ and the city of Świętochłowice $\left(13 \mathrm{~km}^{2}\right)$ are the districts with the largest and smallest area [5].

Linear ordering methods largely contribute to the cognitive value of analyses of complex spatial structures. Essentially, they consist in ordering the objects from the best to the worst with the use of an adequate taxonomic yardstick. This approach provides a synthetic picture of a complex phenomenon (allows the structural similarities and differences to be examined between objects at similar or different levels of a complex phenomenon) [43] (p. 56). When analyzing the standards of living and the financial ability at district level, it is essential to compare a number of investigated objects described using 
a broad mix of variables in such an analysis. Therefore, it is difficult to present the level of these phenomena using a single measurable feature. As a consequence, this study used multidimensional statistical analysis methods based on taxonomic (synthetic) indexes in order to quantify the population's living conditions and the districts' financial capacity and to examine the relations between them. A multidimensional statistical analysis is a mix of statistical methods designed to assess the relations between a number of dependent or co-dependent variables. Some of the multidimensional statistical analysis methods form so-called taxonomy, a science focused on classification problems based on quantitative methods [44] (pp. 16-21). Instead of describing the objects with a series of variables, the indicators describe them with a single aggregated value.

The diagnostic variables used to build the synthetic indicator were selected based on substantive, formal and statistical criteria.

Low accessibility of statistical data makes the unbiased and exhaustive estimation of the living standards across territorial units a difficult task because that aspect is largely determined by the degree to which both physical and intangible needs are addressed. As suggested by A. Zeliaś, the following substantive and formal issues should be considered when selecting the variables [45]:

- $\quad$ polyvalence: the meaning and importance of variables should be widely recognized;

- measurability: the variables must be directly or indirectly measurable and expressed as absolute or relative values;

- $\quad$ numeric data availability: complete numeric information must be available for each variable covered by the study;

- data quality: it must be made sure that the variables collected are not affected by considerable random errors (e.g., typos) and are sufficiently accurate;

- cost-efficiency: the cost of collecting the information must be considered;

- interpretability: the interpretation of variables must be clearly defined;

- impact of variables (a stimulating, inhibiting or neutral effect).

In the first phase of this study, following a substantive and formal analysis of variables, 27 potential diagnostic variables were proposed and broken down into 7 thematic classes basing on substantive criteria (cf. [6] (p. 122), [11] (p. 54)):

(1) labor market: $X_{1}$ : unemployment rate; $X_{2}$ : total number of employed in the national economy per 1000 inhabitants; $X_{3}$ : ratio of average gross remuneration to the national average figure $(\%) ; X_{4}$ : registered unemployed per vacancy; $\mathrm{X}_{5}$ : number of employed in hazardous work conditions per 1000 inhabitants.

(2) healthcare: $X_{6}$ : inhabitants per 1 pharmacy; $X_{7}$ : physicians per 10,000 inhabitants; $X_{8}$ : hospital beds per 10,000 inhabitants; $X_{9}$ : population growth rate per 1000 inhabitants.

(3) environment: $X_{10}$ : industrial and municipal waste-water as a percentage of waste-water which requires treatment; $X_{11}$ : emission of gas pollutants by especially harmful factories in tons per $\mathrm{km}^{2} ; X_{12}$ : proportion of inhabitants operated by treatment plants in the total population;

(4) transport: $X_{13}$ : number of registered passenger cars per 1000 inhabitants; $X_{14}$ : amount of taxicabs per 1000 inhabitants; $X_{15}$ : public (district) hard surfaced roads per $100 \mathrm{~km}^{2}$;

(5) housing conditions: $X_{16}$ : proportion of dwellings having central heating; $X_{17}$ : usable floor area per person; $\mathrm{X}_{18}$ : proportion of dwellings having a bathroom; $\mathrm{X}_{19}$ : proportion of dwellings operated by gas network; $X_{20}$ : share of dwellings served by a sewerage network.

(6) culture: $X_{21}$ : library members per 1000 inhabitants; $X_{22}$ : inhabitants per cinema seat; $X_{23}$ : number of beds in collective living quarters per 1000 population; $X_{24}$ : museums per 1000 inhabitants.

(7) education: $X_{25}$ : primary school pupils per online computer; $X_{26}$ : net enrolment rate for junior secondary schools; $X_{27}$ : kindergarten pupils per 1000 children.

In order to determine the financial capacity of districts, this study used a mix of 11 diagnostic variables mostly related with incomes and expenditures of municipalities located in the districts: $\mathrm{I}_{1}$ : municipal budget income per capita; $I_{2}$ funds allocated by municipalities and districts to finance and 
co-finance union projects and programs per capita; $\mathrm{I}_{3}$ : municipal expenditure per capita; $\mathrm{I}_{4}$ : municipal spending on physical culture per capita; $\mathrm{I}_{5}$ : municipal spending on housing per capita; $\mathrm{I}_{6}$ : municipal spending on culture and national heritage protection per capita; $\mathrm{I}_{7}$ : municipal spending on education per capita; $I_{8}$ : municipal spending on healthcare per capita; $I_{9}$ : municipal spending on atmosphere and climate protection per capita; $\mathrm{I}_{10}$ : municipal spending on transport and communications; $\mathrm{I}_{11}$ : municipal and district-level spending on public debt servicing per PLN 1000 worth of total budgetary income.

The selection of variables mostly depended on the accessibility of comprehensive and current data. In both mixes used in this analysis, the sub-variables have indicator character (not absolute values), which allowed for the restriction of the distortions originating from the fact that particular districts show specific properties (for instance a considerably bigger territory than other units).

As A. Zeliaś rightly points out, an excessively large mix of diagnostic variables makes it much more difficult, if not impossible, to classify multi-feature objects covered by the study [45] (p. 37). Therefore, in the second phase, the discriminating capacity of variables and their capacity, i.e., the degree of correlation with other variables (referred to as the information criterion), was examined in order to obtain the final set of diagnostic variables.

When choosing the variables, particular observations must show satisfactory variation since a non-diversified variable is of low analytical value. The classic coefficient of variation was applied to indicate the diversification of particular variables, expressed as:

$$
V j=\frac{s_{j}}{x_{j}} \cdot 100
$$

where: $s_{j}$-standard deviation of $x_{j} ; \bar{x}_{j}$-arithmetic mean of $x_{j}$.

The assumption was made that the mix of possible variables demonstrating the inhabitants' standards of living and the districts' financial ability was to eliminate the features which show a coefficient of variation less than a critical threshold arbitrarily established at the level of 10\% (this kind of features is quasi-fixed). Due to low values of variation coefficients, the following was eliminated from the mix of variables relating to the inhabitants" standards of living: $X_{18}$ (share of dwellings equipped with a bathroom) and $X_{26}$ (net enrolment rate for junior secondary schools). In turn, nothing was eliminated based on the discrimination criterion from the mix of variables relating to the financial capacity of the observed objects.

The inverse correlation matrix (an approach employed for the discrimination of properties depending on the correlation matrix entries) was used to assess the information value. The inverse correlation matrix was determined for every thematic sub-group [46,47]:

$$
R^{-1}=\widetilde{r}_{j j}, j, j^{\prime}=1,2, \ldots, m,
$$

with $\widetilde{r}_{j j}=\frac{(-1)^{j+j^{\prime}}\left|R_{j j^{\prime}}\right|}{|R|}$ where: $R_{j j^{\prime}}$ is a matrix reduced by removing row $j$ and column $j^{\prime} ;\lceil R\rceil,\left|R_{j j^{\prime}}\right|$ are determinants of matrices $R$ and $R_{j j^{\prime}}$, respectively.

In accordance with this method, the variable corresponding to the highest diagonal entry of the inverse correlation matrix (above the critical threshold value fixed arbitrarily, usually at $r^{*}=10$ ) is removed where needed. Following this, the inverse correlation matrix is recalculated, and the diagonal entries are controlled to find out if they are above the fixed threshold value. This operation lasts until all diagonal entries are not higher than that threshold.

This criterion resulted in eliminating I3 (municipal expenditure per capita) from the mix of variables relating to the districts' financial capacity. In turn, no variable was eliminated based on the information criterion from the set of living standard variables.

The nature of particular variables (the way they impact the developments considered) needs to be identified in order to build the taxonomic indexes of the inhabitant's standards of living and of the districts' financial ability. In other words, it must be determined whether the variables selected have a stimulating, inhibiting or neutral effect based on substantive grounds (with the optimum 
value being set to certain nominal values; any deviations from that value adversely affect the score of the phenomenon considered). Obviously, all variables with a stimulating effect should be positively correlated with one another (the same is true for the variables with an inhibiting effect). Conversely, a negative correlation should exist between the variables with a stimulating effect and those with an inhibiting effect. Also, no statistically significant correlation should exist between the variables with a neutral effect and those with a stimulating effect (and those with an inhibiting effect).

Every variable connected with the districts' financial ability was proven to be stimulant. In turn, while considering variables linked to the inhabitants' standards of living, $X_{1}, X_{4}-X_{6}, X_{11}, X_{22}$, and $X_{25}$ turned out to be de-stimulants. The remaining variables are stimulants.

An essential condition required to use taxonomic methods from eventual diagnostic variables is their comparability (the postulate of additivity). A normalization procedure was performed, taking into account ensuring the comparability of features given with various units as well as of various scales of magnitude. The most widely used normalization methods include: standardization, unitarization and quotient transformation. The values of the variable were subject to a standardization procedure for the purposes of this paper. The objective of standardization is to obtain variables with a distribution with a mean of 0 and a standard deviation of 1 . The most popular standardization formula (cf. [46] (pp. 38-40)) is as follows:

$$
z_{i j}=\frac{x_{i j}-\bar{x}_{j}}{s_{j}}
$$

where: $\bar{x}_{j}$ arithmetic mean; $s_{j}$ : standard deviation of $x_{i j} ; i=1,2, \ldots, n ; j=1,2, \ldots, m$.

A problem which often gives rise to controversies in multidimensional statistical analyses is the method for setting weights. Many authors challenge the procedure for weighing variables referring to spatial data. They suggest that weight coefficients should not be assigned to diagnostic variables, and provide many arguments to support their position, including the fact that variables which are not selected would have a predefined zero weight (cf. [43,46]). In this paper, an assumption was made that diagnostic variables would not be considered on an equal footing. Different weights were attributed to variables depending on their discriminatory and information capacity (separately in both mixes of variables). The modified BVP method (a modification of the method by G. Betti and V. Verma proposed by T. Panek; for a broader description, see [47]) was used for this purpose. It relies on a more adequate measure of information capacity than the linear correlation coefficients used in the original $B V P$ which fail to take the presence of collinearity into account. The analytical form of weights may be expressed as:

$$
w_{j}=w_{j}^{a} \cdot w_{j}^{b}, j=1, \quad 2, \quad \ldots, \quad m
$$

where: $w_{j}^{a}$-measure of discriminatory capacity of diagnostic variable $j ; w_{j}^{b}$-measure of information capacity of diagnostic variable $j$.

The measure of discriminatory capacity, based on the classic coefficient of variation, is expressed as:

$$
w_{j}^{a}=\frac{V\left(x_{j}\right)}{\sum_{j=1}^{m} V\left(x_{j}\right)}, \quad j=1,2, \quad \ldots \quad m
$$

In turn, the measure of information capacity may be defined as:

$$
w_{j}^{b}=\frac{\sum_{\substack{j^{\prime}=1 \\ j^{\prime} \neq j}}^{m} r_{j \cdot j^{\prime}}^{2}}{\sum_{\substack{j=1 \\ j^{\prime} \neq j}}^{m} \sum_{\substack{j^{\prime}=1 \\ j^{\prime} \neq j}}^{m} r_{j \cdot j^{\prime}}^{2}}, \quad j=1, \quad 2, \quad \ldots . m
$$

where: $r_{j \cdot j^{\prime}}^{2}$-squared coefficient of partial correlation between variable $j$ and variable $j^{\prime}$. 
As can be noticed, the measure of discriminatory capacity reaches the greatest value for the variable with the highest coefficient of variation, whereas the measure of information capacity reaches the highest value for the variables with the greatest absolute values of correlation coefficients.

Considering the discriminatory and capacity criteria, within the mix of variables relating to the districts' financial capacity (Table 4), the lowest weight was assigned to variable $I_{7}$ (municipal spending on education per capita) and the highest to variable $\mathrm{I}_{8}$ (municipal spending on healthcare per capita). In turn, regarding the mix of variables referring to the population's living standards, the lowest weight was assigned to variable $X_{10}$ (industrial and municipal waste water as a percentage of waste water requiring treatment) and the highest to variable $\mathrm{X}_{9}$ (growth rate of the population per 1000 inhabitants).

Table 4. Weights of diagnostic variables.

\begin{tabular}{cccccccc}
\hline Variables & Weights & Variables & Weights & Variables & Weights & Variables & Weights \\
\hline I1 & 0.003635 & I11 & 0.004858 & X9 & 0.012126 & X19 & 0.003440 \\
I2 & 0.008416 & X1 & 0.001775 & X10 & 0.000130 & X20 & 0.001841 \\
I4 & 0.009811 & X2 & 0.002575 & X11 & 0.009564 & X21 & 0.001032 \\
I5 & 0.011855 & X3 & 0.000478 & X12 & 0.001776 & X22 & 0.002597 \\
I6 & 0.004324 & X4 & 0.002694 & X13 & 0.000239 & X23 & 0.003449 \\
I7 & 0.002839 & X5 & 0.001164 & X14 & 0.007221 & X24 & 0.001288 \\
I8 & 0.013997 & X6 & 0.000967 & X15 & 0.003907 & X25 & 0.000593 \\
I9 & 0.013755 & X7 & 0.004719 & X16 & 0.000534 & X27 & 0.000812 \\
I10 & 0.008985 & X8 & 0.002867 & X17 & 0.000194 & & \\
\hline
\end{tabular}

The classic TOPSIS approach has been applied to linearly classify the districts by standard of living and financial ability. Using TOPSIS, the synthetic index was built basing on the Euclidean distance both to the positive model solution (pattern) and to the negative model solution (anti-pattern). The shorter the distance to the positive model solution (and the longer the distance to the negative model solution), the greater is the value of the synthetic variable. The steps of building the taxonomic index are as follows [48]:

1. Creating a normalized decision matrix.

2. In the case of weighted variables, the weight matrix and following this the weighted normalized decision matrix need to be created.

3. For the normalized features, the coordinates of the positive ideal $\left(\mathrm{A}^{+}\right)$and the negative ideal $\left(\mathrm{A}^{-}\right)$solution are determined:

$$
\begin{aligned}
& A^{+}=\left(\begin{array}{cc}
\max \left(v_{i 1}\right), & \max \left(v_{i 1}\right), \ldots, \\
i & \left.\max \left(v_{i N}\right)\right)
\end{array}=\left(v_{1}^{+}, v_{2}^{+}, \ldots, v_{n}^{+}\right)\right. \\
& A^{-}=\begin{array}{ccc}
\min \left(v_{i 1}\right) & \min \left(v_{i 1}\right), & \left.\min \left(v_{i N}\right)\right) \\
i & i
\end{array}=\left(v_{1}^{-}, v_{2}^{-}, \ldots, v_{n}^{-}\right)
\end{aligned}
$$

4. Determining the Euclidean distance of each object from the positive ideal solution and the negative ideal solution:

$$
s_{i}^{+}=\sqrt{\sum_{j=1}^{N}\left(v_{i j}-v_{j}^{+}\right)^{2}}, s_{i}^{-}=\sqrt{\sum_{j=1}^{N}\left(v_{i j}-v_{j}^{-}\right)^{2}}, i=1,2, \ldots, M, j=1,2, \ldots, N
$$

5. Calculating the value of the synthetic feature: $C_{i}=\frac{s_{i}^{-}}{s_{i}^{+}-s_{i}^{-}}$, where $0 \leq C_{i} \leq 1$

A correlation analysis was performed to estimate the depth and direction of relations between the inhabitants' standards of living and financial ability based on the nonparametric Spearman rank correlation coefficient [49] (p. 70): 


$$
r_{s}=1-\frac{6 \sum_{i=1}^{n} d_{i}^{2}}{n^{3}-n}
$$

where: $d_{\mathrm{i}}$-difference in ranks (subsequent numbers) between features $\mathrm{X}$ and $\mathrm{Y} ; n$-quantity of sampled elements.

The global Moran's I statistics was applied in order to define the relations between the values of synthetic indexes of living standards and financial ability at district level as well as the analogous values observed in neighboring districts. For a spatial weight matrix, under the assumption that $i$ and $j$ represent selected objects in space, that statistic may be written as follows [50]:

$$
I=\frac{1}{\sum_{i=1}^{n} \sum_{j=1}^{n} w_{i j}} \cdot \frac{\sum_{i=1}^{n} \sum_{j=1}^{n} w_{i j\left(x_{i}-\bar{x}\right)\left(x_{j}-\bar{x}\right)}}{\frac{1}{n} \sum_{i=1}^{n}\left(x_{i}-\bar{x}\right)^{2}}
$$

where: $x_{i}, x_{j}$-values recorded in locations $i$ and $j(i, j=1,2, \ldots, n), \bar{x}$-mean value in every territory studied, $w_{i j}$-entries of the spatial weight matrix.

A value of 0 means spatial randomness, i.e., lack of spatial autocorrelation (the numeric characteristics of the phenomenon in one territory do not depend upon the characteristics of adjacent territories). Positive and significant $I$ values indicate the existence of positive autocorrelation (i.e., similarity of the examined objects). Conversely, negative $I$ values mean negative autocorrelation (i.e., differentiation of the examined objects). Positive autocorrelation means that objects with similar values are grouped into clusters, while negative autocorrelation is interpreted as "hot spots," i.e., isolated areas where distinctly different values are recorded [51] (p. 72).

The local Moran's $I_{i}$ statistics, kind of the Local Indicators of Spatial Association (LISA), was applied to find the proportion of global autocorrelation for individual location in the territory analyzed. For non-standardized variable values and for a weight matrix standardized by rows, the local Moran's $I_{i}$ statistics was determined using the formula below [50]:

$$
I_{i(w)}=\frac{\left(x_{i}-\bar{x}\right) \sum_{j=1}^{n} w_{i j}^{*}\left(x_{j}-\bar{x}\right)}{\sum_{i=1}^{n}\left(x_{i}-\bar{x}\right)^{2}}
$$

where: $w_{i j}$ - entries of the spatial weight matrix of rank 1 standardized by rows; $x_{i}, x_{j}$-values observed in locations $i$ and $j(i, j=1,2, \ldots, n) ; \bar{x}$-mean value in every investigated territory analyzed.

A spatial regression analysis was performed to estimate the depth of spatial relations between the taxonomic indexes of the standards of living and the districts' financial ability. Spatial models may be understood as a particular development of "classical econometric models (the "classical" regression analysis includes creating models-based on a series of possible modeling methods, which provide a quantitative description of relations between the dependent variable and the mix of one or multiple independent variables) enhanced with supplementary variables in order to involve the spatial relations. This is important in that the values of the variable under consideration determine, and are determined by, the corresponding values recorded in other locations (observations in different locations are not independent of one another). The existence of spatial relations supports transformations of the features of structural parameters within models determined with the classical least squares (CLS) method. The purpose of spatial modeling is to enhance the specifications of the econometric model. Generally, spatial interactions can involve the following [50]: the explained variable (this means spatial autoregression, i.e., a situation, in which the values of the endogenous variable recorded in other locations influence the values of that variable in location $i$ ); the explanatory variable (if the endogenous variable in location $i$ is affected by values of exogenous variables recorded in other locations); the random component (if the model does not or cannot include certain spatially autocorrelated variables).

According to the commonly used approach for choosing spatial regression models, the CLS method was employed in order to determine the structural parameters within the linear regression 
model while starting the analysis. The outcomes of the Jarque-Bera test (see Table 5) do not give grounds for rejecting the hypothesis of normal distribution of the random component. Consequently, the values of asymptotic Lagrange multiplier tests may be determined, and the maximum likelihood method may be employed as well. It is of particular importance, since if spatial autocorrelation occurs, the classical estimator basing on the CLS method may mismatch (or be at least ineffective) for example with SEM models. Spatial tests were performed and assessed for significance as the next step. These tests enable the diagnosis of the determined spatial models (allow indication of the kind of spatial interaction between the phenomena studied) which are some kinds of modifications used in "classical" models. The downside of the Moran's I test is that it does not allow for the determination of the type of spatial autocorrelation. Therefore, the $\mathrm{LM}_{\mathrm{SEM}}$ and $\mathrm{LM}_{\mathrm{SAR}}$ Lagrange multiplier tests were applied to estimate the kind of spatial autocorrelation of the random component and of the explained variable, respectively. The tests were performed for a linear regression model estimated by classical least squares.

Table 5. Outcomes of the estimation for the entrepreneurship model: the classical model and the spatial error model.

\begin{tabular}{ccc}
\hline \multirow{2}{*}{ Models } & \multicolumn{1}{c}{ Classical Model } & SEM \\
\cline { 2 - 3 } & \multicolumn{2}{c}{ Estimation } \\
\hline$\lambda$ & - & $0.1401(0.0480)$ \\
Intercept & $0.2021(0.0000)$ & $0.2028(0.0000)$ \\
SIFC & $0.4036(0.0000)$ & $0.3996(0.0000)$ \\
AIC & -741.2940 & -745.2380 \\
SC & -733.4140 & -737.3570 \\
Log likelihood & 372.6470 & 374.6189 \\
\hline \multicolumn{3}{c}{ Normality Test } \\
JB & $1.1331(0.5675)$ & - \\
BP & Heteroscedasticity Tests \\
KB & $2.9024(0.0885)$ & $3.3112(0.0688)$ \\
\hline & $2.7854(0.0951)$ & - \\
Moran $I_{\text {error }}$ & Spatial Autocorrelation Tests \\
LM & $2.1420(0.0322)$ & - \\
LMAR $_{\text {SEM }}$ & 3.1697 (0.0750) \\
\hline
\end{tabular}

Notes: the determined significance levels for the rejection of the null hypothesis are placed in brackets. $\lambda:$ spatial autocorrelation parameter; AIC: Akaike Information Criterion; SC: Schwarz Criterion; Log likelihood: logarithm of the likelihood function; JB: Breusch-Pagan test; KB: Koenker-Bassett test; Moran Ierror: Moran's I error significance test; $\mathrm{LM}_{\mathrm{SAR}}$ : Lagrange multiplier test for SAR; $\mathrm{LM}_{\mathrm{SEM}}$ : Lagrange multiplier test for SEM.

If spatial autocorrelation of residuals is detected, spatial estimation techniques must be applied. Two models' categories that identify that kind of spatial relations: SAR/SLM (spatial lag models) and SEM (spatial error models) may be distinguished.

The spatial lag model covers the so-called spatially lagged endogenous variable, which means that this is an autoregression model. Consecutively, the spatial error model includes the presence of spatial autocorrelation between residuals. The existence of spatial autocorrelation in the error term of the model may originate from the omission of non-observed variables which could be spatially correlated [51].

The basic spatial lag models (SLM) may be expressed by the formula:

$$
y=\beta X+\rho W y+u, \quad u \sim \operatorname{IIDN}(0,1),
$$


where: $X$-matrix of independent variables; $\beta$ : vector of coefficients; $W$-matrix of spatial weights; $\rho$-spatial autocorrelation coefficient; $u$-model's error term; $W y$-spatial lag of dependent variable (understood as the level of dependent variable $y$ in neighboring regions).

The basic spatial error models (SEM) may be expressed by the formula:

$$
y=\beta X+u, u=\lambda W u+\varepsilon, \quad \varepsilon \sim \operatorname{IIDN}(0,1),
$$

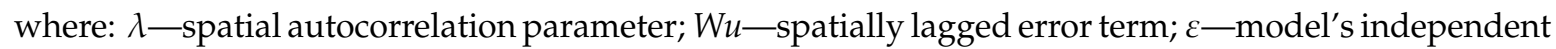
error term.

As mentioned earlier, the Lagrange multiplier tests were employed to find the kind of spatial relations: $\mathrm{LM}_{\mathrm{SEM}}$ (for the autocorrelation of the random component) and $\mathrm{LM}_{\mathrm{SAR}}$ (for the autoregression of the considered variable). If both tests prove to be statistically insignificant, no spatial autocorrelation exists; the linear regression model should be used. The models' residuals built based on the CLS method and on the weight matrix standardized by rows were applied in order to verify the null hypothesis on the absence of spatial autocorrelation in the error term. The following statistic was employed for that purpose:

$$
L M_{\text {SEM }}=\left(\frac{1}{T_{1}}\left(\frac{e^{T} W e}{\hat{\sigma}^{2}}\right)^{2}\right) \stackrel{\text { as }}{\sim} \chi_{(1)^{\prime}}^{2}, \quad T_{1}=\operatorname{tr}\left[\left(W^{T}+W\right) W\right]
$$

where: $\operatorname{tr}[$.$] - trace of a matrix; e$ - vector of model's residuals the estimated using the CLS method; $\hat{\sigma}^{2}$-residual variance estimator.

In the second case, the null hypothesis (with $H_{0}: \rho=0, H_{1}: \rho \neq 0$ ) is verified with the following statistic:

$$
L M_{S A R}=\left(\frac{1}{T_{2}}\left(\frac{e^{T} W y}{\hat{\sigma}^{2}}\right)^{2}\right) \underset{\sim}{\text { as }} \chi_{(1)^{\prime}}^{2} \quad T_{2}=T_{1}+\frac{(W X \hat{\beta})^{T} M_{X}(W X \hat{\beta})}{\hat{\sigma}^{2}}
$$

where: $M_{x}=\frac{e^{T} W e}{e^{T} e}-X\left(X^{T} X\right)^{-1} X^{T}, \hat{\beta}$ - estimator expressed as $\hat{\beta}=\left(X^{T} X\right)^{-1} X^{T} y$

The spatial interaction type selected is the one with a higher $L M$ value.

While considering spatial regression models, besides spatial relations as autoregression or autocorrelation of the random component, the analysis ought to cover spatial heterogeneity as well, i.e., the instability in the space of relations (that may have, for example, economic nature). That may be an effect of a number of factors, such as the asymmetry of the relations between central and distant territories. Spatial heterogeneity may result from an inaccurate specification of the model as well; if so, the spatial distribution of model errors is the same as the distribution of the variable not included in the model.

Econometric models may address these differences in two ways [50]: based on variability in variance of the random component (if the problem of heteroscedasticity of the random component emerges in the economic model; this is caused by the failure to take significant explanatory variables into account or by other errors in the specifications) or based on variability in structural parameters (if the parameters of the regression model vary across locations).

Heteroscedasticity can be verified using the Breusch-Pagan (BP) test. The test statistics is expressed by the formula:

$$
B P=\frac{1}{2}\left[g^{T} Z\left(Z^{T} Z\right)^{-1} Z^{T} g-N\right]_{\sim}^{a s} \chi_{(k)}^{2}
$$

where: $g$-vector formed basing on residuals of the model created with the CLS method; entries of the vector are $g_{i}=\frac{e_{i}^{2}}{\left(\frac{e_{T} T_{e}}{N}\right)}, Z$ is the complete matrix of explanatory variables, $N$ is the total quantity of units (for instance, districts). 
Another routine which may employed is the Koenker-Bassett test basing on the test statistics expressed as:

$$
K B=\frac{1}{\operatorname{Var}\left(\varepsilon^{2}\right)}(u-\overline{u i})^{T} Z\left(Z^{T} Z\right)^{-1} Z^{T}(u-\overline{u i})
$$

where: $\operatorname{Var}\left(\varepsilon^{2}\right)=\frac{1}{N} \sum_{i=1}^{N}\left(e_{i}^{2}-\frac{e^{T} e}{N}\right)^{2}, u=\left[e_{1}^{2} e_{2}^{2} \ldots e_{N}^{2}\right], \bar{u}=\frac{e^{T} e}{N}$

\section{Findings from the Study: Analysis of Spatial Relations between the Districts' Financial Capacity and the Inhabitants' Standards of Living}

The conclusion from the above analyses is that the greatest values of synthetic indexes of the inhabitants' standards of living were found in urban districts, which ranked 1st to 16th (see Table A1 in Appendix A). In this context, note that municipal (urban) districts accumulate a significant part of the voivodeship's social and economic potential (comprising business environment institutions and cultural ones). That may have impact on the so-called "big city shadow," and might be mirrored by a lowering of factors influencing the standards of living in the neighboring districts. This is largely why districts which share a border with current or former voivodeship capitals (e.g., Biała Podlaska, Przemyśl, and Zamość districts) can be observed to be ranked at the bottom. The highest value was recorded in the city of Sopot, mainly because of high values of variables referring to the average gross remuneration, number of taxicabs per 1000 inhabitants, the percentage of dwellings having central heating, and the number of public library members. Of the ten districts with the lowest indexes of the inhabitants' standards of living, eight are located in Eastern Poland voivodeships. In the case of 3/4 of districts, the synthetic index of standards of living was less or equal to 0.5470 with a maximum at 0.6993 and a minimum at 0.4518 . The synthetic index showed right-side asymmetry (the coefficient of skewness at the level of 2.85 (own calculations based on [5]). This indicates that the values not above the arithmetic mean dominated.

The results show that indicators of financial capacity (see Table A2) vary moderately within the districts analyzed. As at 2017, the maximum-to-minimum ratio totaled 3.51, whereas the coefficient of variation exceeded $15.34 \%$. Nine out of ten districts with the highest levels of the synthetic indicator of financial capacity were urban districts. The sole exception was the Polkowice district whose economy relies primarily on the extractive industry. It is a home to KGHM Polska Miedź S.A., one of the largest producers of copper and silver in the world. The highest value of the indicator was recorded in Warsaw. This comes as no surprise since, according to estimations by the Cologne Institute for Economic Research (IW Köln) [52], without Warsaw, the Polish GDP would decrease by ca. 10\%. Note also that in 2018, Warsaw was ranked 11th in the European Cities of the Future index published in the prestigious Foreign Direct Investment Intelligence report, above such cities as Berlin and Stockholm (in the European business-friendly cities category, only London and Dublin ranked higher than the Polish capital) [53]. It is difficult not to agree with B. Guziejewska who finds that the general financial situation of urban districts is quite good compared to other local government units because of a more advantageous share of own incomes in the income mix and a higher income per capita [54] (p. 20).

The smallest levels of synthetic indexes were recorded in Kluczbork, Milicz and SkarżyskoKamienna districts. That mostly results from small or very small values of variables relating to: funds allocated by municipalities and districts to finance and co-finance union projects and programs; municipal spending on healthcare; and municipal spending on atmosphere and climate protection. Considering $75 \%$ of districts, the synthetic index of financial capacity was lower or equal to 0.3019 with a maximum at 0.5176 and minimum at 0.1475 . The taxonomic index of financial ability proved right-side asymmetry (skewness coefficient at the level of 4.86) (own calculations based on [5]).

To ensure completeness of analysis of indicators calculated using TOPSIS, the districts were grouped by similarity of the inhabitants' standards of living and districts' financial ability (based on percentile scores) (Figure 2). 

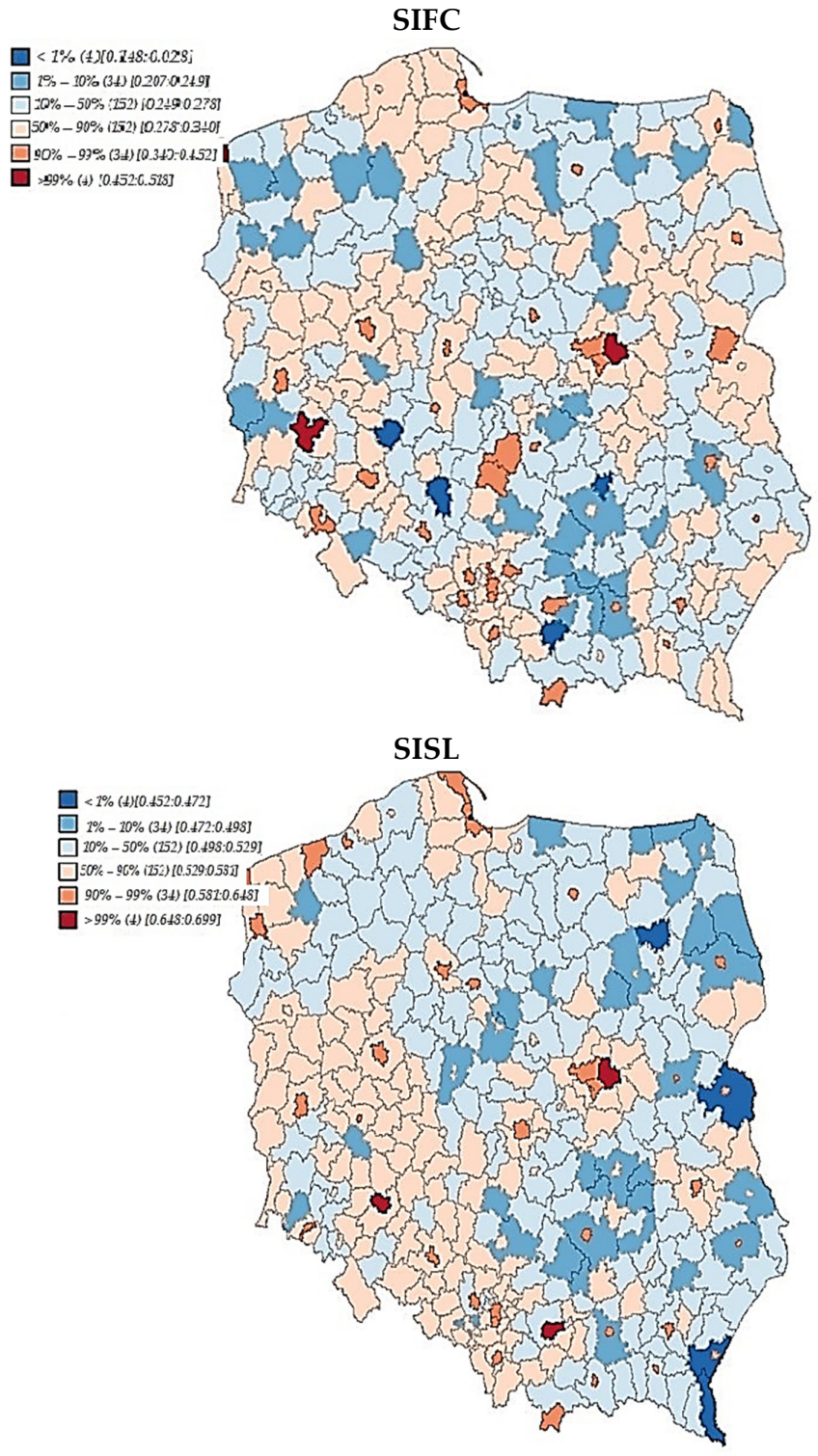

Figure 2. Percentile map of synthetic index for the inhabitants' standards of living and districts' financial ability.

The percentile maps allowed to identify (and corroborate) certain spatial patterns, namely:

- $\quad$ urban districts prevail in the group of districts with the greatest financial capacity and the highest inhabitants' standards of living;

- $\quad$ as regards the variables covered, no clear differences in the standards of living exist between the western and the eastern parts of Poland; however, a greater number of districts belonging to the first two groups (with the lowest standards of living) were found in the eastern part;

- $\quad$ when it comes to financial capacity, former or current voivodeship capitals (the 1999 reform of the country's administrative division resulted in reducing the number of voivodeships from 49 to 16) usually belonged to a group at a higher level than the corresponding land districts (which share a border with them);

The Spearman rank correlation coefficient between the specified taxonomic indexes amounted to 0.4696. This suggests a moderately high relation between the occurrences analyzed and gives grounds for concluding that the correlation coefficient was significant at $p<0.05$. 
As A. Zeliaś rightly points out, the analysis of socio-economic occurrences basing on crosssectional data ought to comprise the influence of the spatial structure of units (for instance, districts) on the phenomena studied. It results from the fact that the spatial structure is generally affected by particular determinants, mostly of historic, cultural or sociological character. Consequently, spatial relations (so-called spatial autocorrelation) can be present between neighboring units [55]. According to J. Korol and P. Szczuciński, the essential reason behind spatial relations is the fact that certain properties of territories are not functions of their other properties; instead, they result from inter-territorial relations and from the accompanying impacts [44] (pp. 63-64).

Spatial relations are generally believed to have two causes. First, a spatial relation may be related to measurement errors or random component affecting the territorial units (the errors are a consequence of inconsistencies between the range of the phenomenon considered and the territorial division into continuous units). If the phenomenon prevails only in a certain part of a territorial unit, its level and measurement error are aggregated within the entire unit. Second, spatial relations may result from data aggregation into larger territorial units; meanwhile, data aggregation and inconsistencies between territorial limits and the boundaries of the phenomenon are aspects which usually increase errors [56] (p. 11).

Spatial autocorrelation exists if "the prevalence of a phenomenon in one spatial unit results in increasing or decreasing the likelihood of its prevalence in neighboring units" [57] (p. 9). Spatial autocorrelation is understood as the correlation degree between the identified value of a variable in a specific location and the value of the same variable in another location. It indicates that the values of the variable under consideration determine, and are determined by, the corresponding values recorded in other locations. There exist two types of spatial correlation: positive autocorrelation and negative autocorrelation. Positive autocorrelation means spatial concentration of high or low values of a variable. In turn, negative autocorrelation indicates that high and low values are close to each other [50] (p. 103).

The essential problem in the spatial autocorrelation analysis is to define neighborhood structures based on what is referred to as spatial weights which allow location-specific relations between units to be taken into account. The starting point is to set the assumptions for the way of defining the neighborhood. Spatial relations are quantified with the use of a spatial weight matrix. They are based on the distance or neighborhood matrix (the weights are non-zero if two locations share a border or are separated by a predefined distance). The study concept in this article assumes that a shared border (examples of other criteria for the construction of the matrix include: k nearest neighbors; number of neighbors within $n$ kilometers; distance between the centers of the territories; inverse distance between neighbors) is the proximity criterion (mutual neighborhood was assumed to have a positive influence on the formation of links between spatial units; conversely, an increased distance between units has an inhibiting effect). This is the most widely adopted neighborhood modeling method which uses a binary matrix as the starting point: the symbol 1 means that the areas share a border; 0 means they do not. This is a symmetric square matrix (cf. [58,59]).

As mentioned earlier, the global Moran's I have been applied into the analysis of the relations between the values of synthetic indexes of living standards and districts' financial ability and the analogous values observed in neighboring districts. The global Moran's I statistics created for the synthetic index of financial capacity for districts was positive and amounted to 0.1419 ; the standards of living taxonomic index totaled 0.2379 . It was statistically significant in the first and the second case. The global statistical significance test was based on the histograms analysis of the randomized permutation test. The hypothesis was verified with the use of the pseudo-significance level. The quantity of permutations amounted to 9999.

When analyzing the values of global autocorrelation, it should be borne in mind that these statistics depend on the aggregation degree of the areas considered [50] (p. 116). A greater aggregation (e.g., at macroregion level) may result in identifying a strong negative autocorrelation whereas at the level of smaller areas, the analysis may result in identifying a positive autocorrelation (Figure 3). 


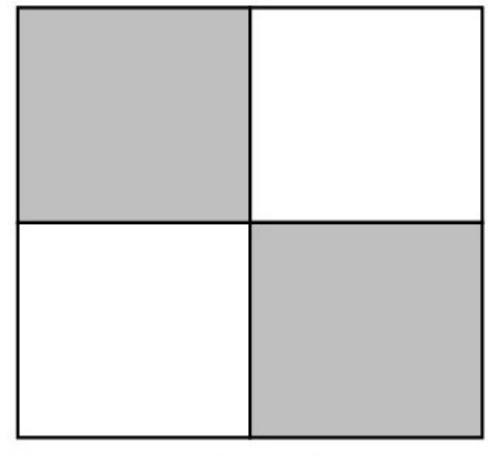

$I=-1$

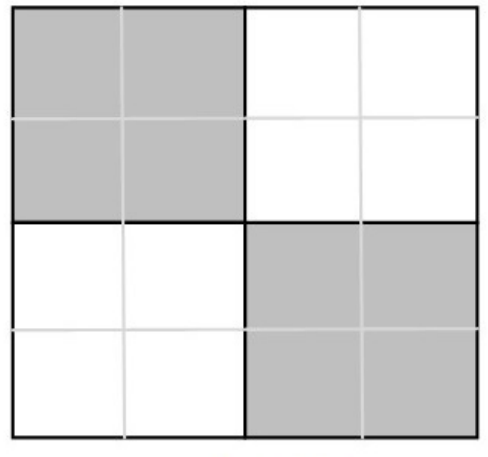

$I=0.33$

Figure 3. Relation between global spatial autocorrelation and the aggregation scale.

A dot plot of the global Moran's I statistics was created (Figure 4) for a more in-depth analysis. It constitutes an image of the distribution of the analyzed variables in particular spatial units compared to their spatial lag determined according to the declared weights' matrix. On the OX axis the value of the standardized variable is presented (expressed as a number of deviations from the mean), whereas on the OY axis the standardized variable (weighted average for neighboring areas). The diagram of dispersion presents the investigated occurrence in the following set: in the quadrant I of the coordinate system, there are points representing areas of high level of the occurrence, whose neighboring objects are characterized by a high level of the occurrence; in quarter II of the coordinate system there are points representing areas of low level of occurrence and high values in the bordering territories; in quadrant III there are areas of low level of the analyzed occurrence, bordering with territories with low values as well, in quadrant IV there are areas of high values of the analyzed occurrence, neighboring with territories in which the low values were observed. The slope of the regression line included in the graph is equal to the value of the global Moran's I statistics. As most of the points are located in quadrant III of the graph of the global Moran's I statistic for both aspects under consideration, it may be assumed that most of the objects (districts) analyzed are clustered by low levels of both the taxonomic index of the inhabitants' standards of living and the indicator of the districts' financial ability.
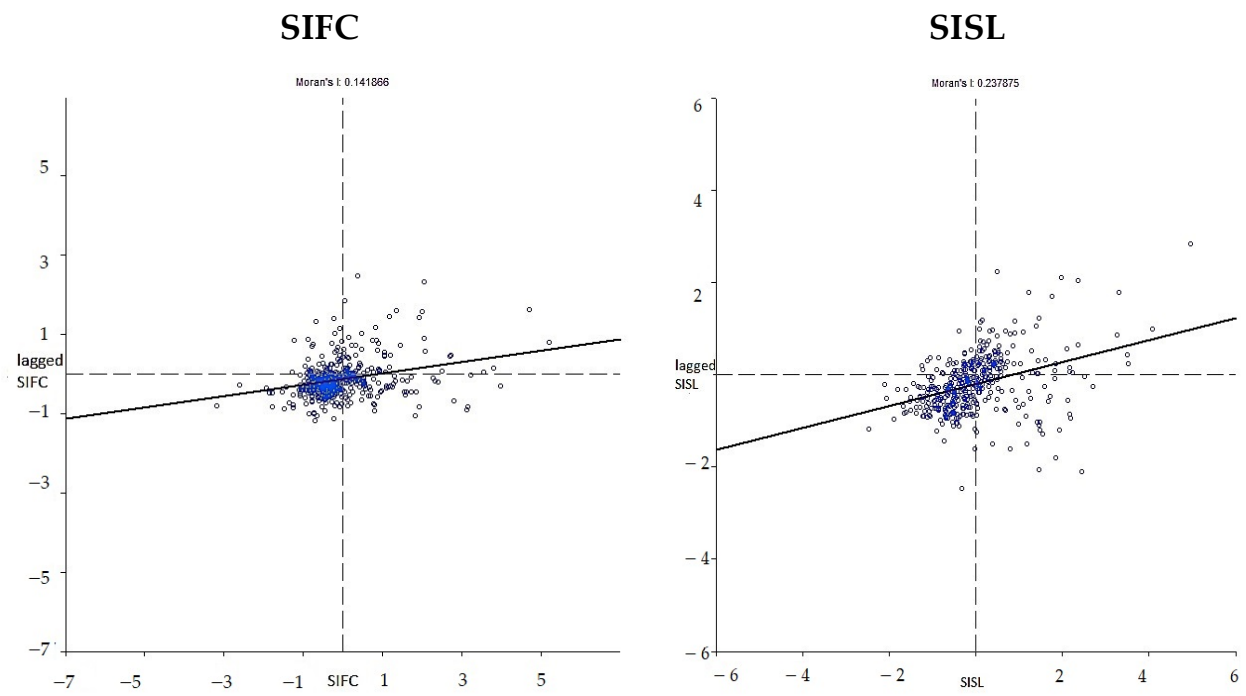

Figure 4. Dispersion graph for synthetic indicators of financial ability district level and of the inhabitants' standards of living.

The use of the global spatial autocorrelation coefficient (Moran's I) enables the detection of the strength and nature of the spatial relation present in the study area. Its value determines the nature of 
the averaged pattern of spatial autocorrelation in this area. However, it is insensitive to local deviations from the averaged pattern of spatial autocorrelation and does not include information on the pattern's degree of instability. Hence, neither the areas with a locally stronger (positive) spatial relations nor the outliers (associated with a locally negative spatial autocorrelation) may be identified. The local statistic, calculated for each spatial unit, is a way to circumvent this inconvenience. as it allows to be determined whether an area is surrounded by neighboring units with large or small values of the variable under consideration [60] (p. 27).

Local statistics values allow for the determination of clusters of areas with analogous levels of the feature under consideration and areas which differ in the value of taxonomic indicators of financial ability at district level and of the inhabitants' standards of living (Figure 5).

Using local Moran's I statistics 33 low-low areas (demonstrating small values of the variable analyzed) were distinguished for the synthetic indexes of the districts' financial ability. They included a group of seven districts located in the Zachodniopomorskie and Wielkopolskie voivodeships and a compact cluster of 12 districts located in the Łódzkie, Mazowieckie, Świętokrzyskie, and Małopolskie voivodeships. The structure of areas was also investigated to embrace 14 high-high areas (a great value of the index bordering with great values), including a large cluster of seven units placed in the central part of the Mazowieckie voivodeship. six territorially dispersed high-low areas (a great value of the index bordering with small values) and six low-high territories were specified as well.

Twenty high-high units (including 10 neighboring districts located near Warsaw) were found using the cartograms of local Moran's I statistics built for the taxonomic indexes of the inhabitants' standard of living. An amount of 69 low-low areas were specified as well (primarily including the very extensive compact cluster of 18 districts spanning from the northern part of the voivodeship (Mława and Przasnysz districts) to the Sokółka and Augustów districts at the eastern border of the country and to the Łosice district (the most eastward district of the Mazowieckie voivodeship).

A spatial regression analysis was performed in order to measure the depth of spatial relations between the taxonomic indexes for the standards of living and the districts' financial ability.

The results indicate (see Table 5), that there is a spatial autocorrelation between residuals (as reflected by the small $p$-value for the Moran's I statistic determined for the regression residuals). Therefore, spatial estimation techniques must be applied in this model. Considering the fact that the value of the $L M_{S E M}$ test was statistically significant $(p<0.05)$, the SEM was employed afterwards during the study.

The last column of Table 5 presents the outcomes of the SEM model estimation based on the maximum likelihood method. The structural form determined model might be expressed:

$$
\begin{gathered}
S I S L=0.2028+0.3996 \cdot \operatorname{SIFC}+u, \\
u=0.1401 \cdot W u+\varepsilon
\end{gathered}
$$

where: SISL — synthetic index of the standards of living; SIFC—-taxonomic index of financial ability at district level; $W u$-spatially lagged error term (mean error in neighboring areas); $\varepsilon$-model's independent error term. ion coefficient is statistically significant, which indicates that the variables involved influence the taxonomic index for standards of living in the districts under consideration.

The statistical significance of $\lambda(0.1401, p$-value $=0.0480)$ proves the presence of spatially autocorrelated extra-model determinants that impact the standards of living, which indicates that the model does not consider particular non-observed (for instance, non-measurable or random) variables that may be spatially correlated. In turn, according to E. Lechman, a statistically significant $\lambda$ value can be interpreted as the existence of spatial autocorrelations caused by random non-modellable factors and/or measurement errors [61]. It may also be assumed that the external shock in an individual region in the spatial error model does not impact the condition of the specified region exclusively but also the situation of neighboring regions due to the occurrence of a spatial dependency of errors [51] (p. 133). 


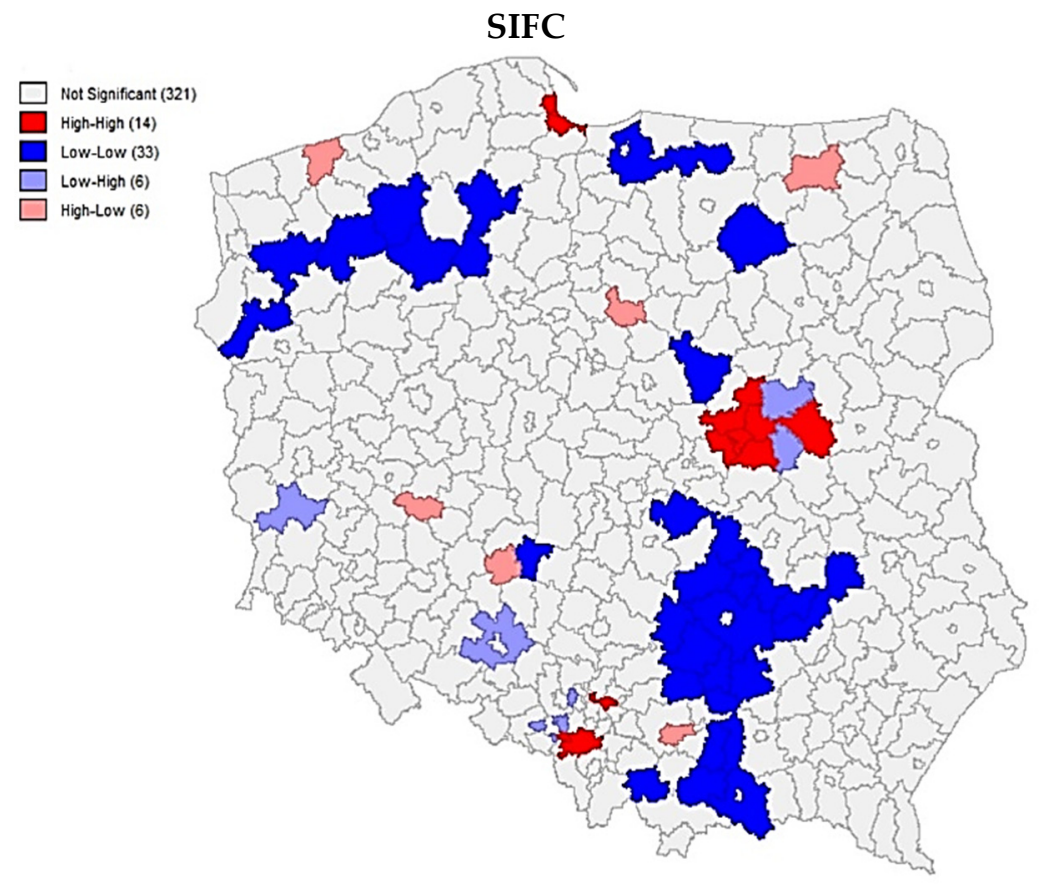

SISL

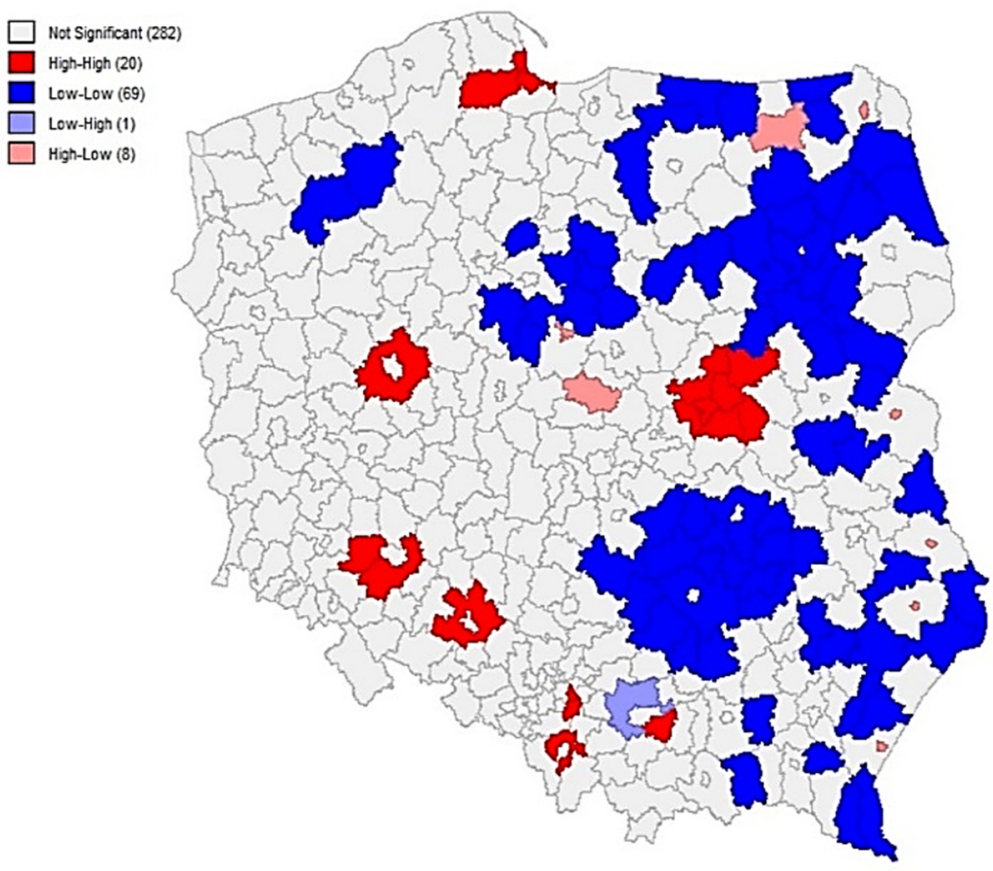

Figure 5. Cartogram of values of the local Moran's I statistics according to cluster type.

Every regress In the case of the spatial error model, the parameter of the explanatory variable can be interpreted as a partial derivative, i.e., a change of the explained variable triggered by a change in the explanatory variable with other explanatory variables remaining constant [62] (p. 146). The determined SEM model constitutes a basis to conclude that (as at 2017) about $1 \%$ growth of the value of the taxonomic index for the districts' financial ability causes, other things being equal, a $0.4 \%$ growth in the taxonomic index for the standards of living of the districts' population.

The adjusted $R^{2}$ for the estimated spatial error model amounted to 0.6259 , whereas for the classical model it totaled 0.6195. In this context, note that the particularities of the model's structure and the use of the estimation procedure based on the maximum likelihood method are the reasons why 
the classical coefficient of determination cannot be used in measuring the model's goodness of fit. Instead, the "pseudo- $R^{2}$ " can be used which shows the share of explained variance in total variance [50] (pp. 293-294):

$$
\text { pseudo }-R^{2}=\frac{S^{2}(\hat{y})}{S^{2}(y)}
$$

The application of the spatial model influenced a small decline in the standard estimation error (0.0901 for SEM and 0.0908 for the classical model). The relatively small differences between the indicators of the models' goodness of fit suggest that including spatial interactions did not considerably affect the determination of the ranks of structural parameters (in spite of the existence of spatial clusters of districts at low or high values of synthetic index specified in the analysis).

The model that involves the mean error in neighboring areas can be considered to be more appropriate than the model based on the CLS method, taking into account the Akaike and Schwarz information criteria. Analogous statement can be made based on the likelihood logarithm (the model with the higher value is the better one).

Both Breusch-Pagan and the Koenker-Bassett test (see Table 5) did not allow for the rejection of the null hypothesis on the homoscedasticity of the random component (at $p>0.05$ ). The linear regression model built, might have been employed for the study, avoiding the necessity of implementing any supporting variables (showing the parameters' variability, for instance east/west). If the model's residuals were heteroscedastic, binary modeling of spatial regimes would be the right solution.

\section{Conclusions}

The fundamental task of local authorities is to form the conditions supporting improvements in the inhabitants' standards of living. The range, the lasting life performance of the important activities are related considerably to the local government units' financial capacity. This paper attempted to present the financial capacity of districts as a factor which has a differentiating effect on the inhabitants' standards of living. It seems that the analyses of the differences in the inhabitants' standards of living are of particular importance for the socioeconomic cohesion policy designed to narrow the development gap.

The conducted analyses indicate that there is a statistically significant correlation between the districts' financial ability and the standards of living. The Spearman rank correlation coefficient between the specified taxonomic indexes was 0.4696 . The outcomes of the spatial regression analysis allow the conclusion that about $1 \%$ increase in the synthetic index of the districts' financial ability (as at 2017) reflects a $0.4 \%$ growth of the taxonomic index for the standards of living of the inhabitants of different districts (other things equal). The existence of spatial autocorrelation for the model's residuals indicates that the presence of external factors in an individual district will cause modifications in neighboring areas, too.

As shown by research results, and what comes as no surprise, the highest standards of living of the inhabitants were found in urban districts (which ranked 1st to 16th in this study). The highest value was recorded in the city of Sopot whereas the lowest values of the indicator defined in this study were observed in eastern Poland districts (Przemyśl, Biała Podlaska, and Bieszczadzki districts). As regards three quarters of the investigated objects, the synthetic index of financial ability was less or equal to 0.3019 with a maximum at 0.5176 (Warsaw) and minimum at 0.1475 (Skarżysko- Kamienna district).

Narrowing the development gap (and, as a consequence, the gap in the standards of living) at local and regional level becomes a major challenge to today's economy. The results of analyses (e.g., the ranking of districts by the population's standard of living) can be applied indirectly by a number of stakeholders, e.g., local authorities responsible for local and regional development, while creating the developmental strategies by local authorities. The knowledge on spatial development structures can enhance the formation of the strategic management process (for instance, redefining the objectives and tasks set out in local strategies; restructuring the expenditure to meet the local population's needs). It could also be an incentive for local authorities to take measures focused 
e.g., on aligning the public services with the population's expectations or developing the economic and social infrastructure intended to improve the population's standards of living (e.g., building crèches or a gas network). The analysis of the stimulants of the standard of living in particular countries (both industrialized and developing) has an important meaning in the context of the efficient implementation of the sustainable development concept (which in a broader meaning means a strategy of the standard of living improvement-without degrading natural resources and ecosystems). Therefore, an identification of "standards of living clusters"-concentration of the neighboring areas characterized by high or low standard of living. The standard of living in one territorial unit may have an impact (positive or negative) on standard of living in neighboring units (e.g., regarding to inhabitants' mobility, transboundary character of infrastructure). Therefore, the research results may constitute an incentive for cooperation of the local authorities in the area of standards of living improvement (spreading good practices) and creating this way a synergy effect. Satisfaction of collective needs of particular LGUs is a basic task for local authorities and simultaneously a necessary condition for location and development of business activity. The outcomes of the conducted research may be indirectly used by the local authorities responsible for local and regional development in the context of choice of direction of socio-economic restructuring and formation of long term development strategy of specific LGUs, taking into account rational financing of the measures of particular meaning for satisfying the collective needs of inhabitants.

With respect to performing further studies, the remaining spatial statistics might be applied, e.g., global (for instance Geary's C) as well as local (for instance, the Getis-Ord statistics). On the other hand, the remaining spatial neighborhood structure (higher-order neighborhood) might be used. Obviously, the level of data aggregation and the area of territories investigated also had an impact on the outcomes of this study. It would additionally be useful to analyze smaller spatial units or put the analysis in an international context. However, the small extent of potential diagnostic variables available at that level of data aggregation is a major problem.

Author Contributions: Conceptualization, M.M.; methodology, M.M.; software, M.M.; validation, M.M.; formal analysis, M.M. and J.S.-S.; investigation, M.M. and J.S.-S.; resources, M.M.; data curation, M.M.; writing—original draft preparation, M.M. and J.S.-S.; writing—review and editing, M.M. and J.S.-S.; visualization, M.M.; supervision, M.M. and J.S.-S.; project administration, M.M. and J.S.-S. All authors have read and agreed to the published version of the manuscript.

Funding: This research received no external funding.

Conflicts of Interest: The authors declare no conflict of interest.

\section{Appendix A}

Table A1. Chosen values of the taxonomic indexes for districts' standards of living, determined using TOPSIS method (50 greatest and 50 smallest values).

\begin{tabular}{|c|c|c|c|c|c|c|c|c|}
\hline District & SISL & $\mathbf{R}$ & District & SISL & $\mathbf{R}$ & District & SISL & $\mathbf{R}$ \\
\hline st. Warszawa & 0.6695 & 2 & Zielona Góra & 0.5821 & 36 & sokólski & 0.4967 & 349 \\
\hline Wrocław & 0.6504 & 4 & Nowy Sącz & 0.5812 & 38 & zwoleński & 0.4964 & 351 \\
\hline Gdańsk & 0.6437 & 5 & Gorzów Wlkp. & 0.5808 & 39 & jędrzejowski & 0.4945 & 352 \\
\hline Poznań & 0.6424 & 6 & grodziski & 0.5804 & 40 & moniecki & 0.4941 & 353 \\
\hline Biała Podlaska & 0.6158 & 9 & Słupsk & 0.5761 & 43 & lipnowski & 0.4936 & 356 \\
\hline Gdynia & 0.6126 & 10 & piaseczyński & 0.5747 & 44 & gołdapski & 0.4934 & 357 \\
\hline Bielsko-Biała & 0.6126 & 11 & lubiński & 0.5746 & 45 & rybnicki & 0.4929 & 358 \\
\hline Lublin & 0.6085 & 12 & Suwałki & 0.5735 & 46 & łobeski & 0.4924 & 359 \\
\hline Olsztyn & 0.6068 & 13 & Skierniewice & 0.5729 & 47 & siedlecki & 0.4913 & 360 \\
\hline
\end{tabular}


Table A1. Cont.

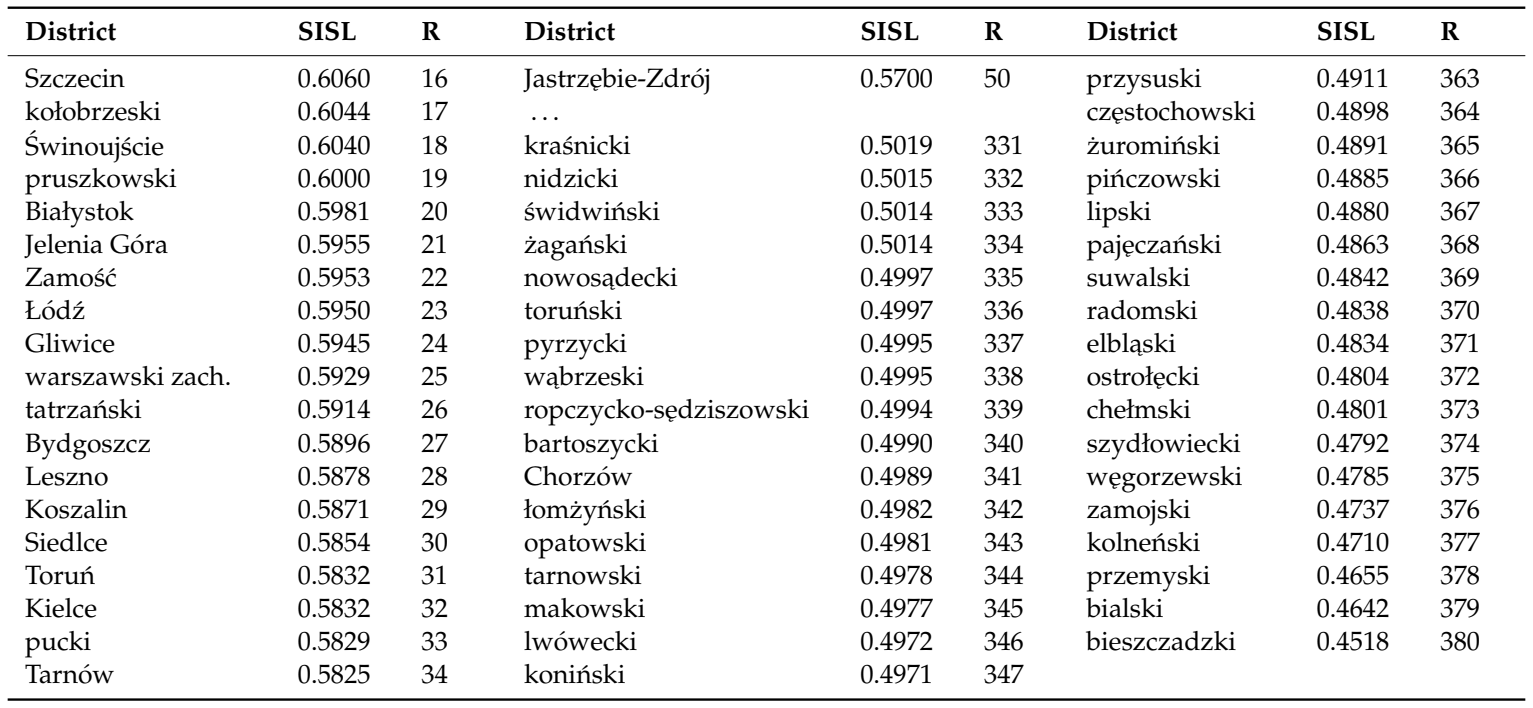

Notes: SISL-synthetic index for the standards of living; R—rank.

Table A2. Chosen values of the synthetic index for financial ability at district level, determined using TOPSIS method (50 greatest and 50 smallest values).

\begin{tabular}{|c|c|c|c|c|c|c|c|c|}
\hline District & SIFC & $\mathbf{R}$ & District & SIFC & $\mathbf{R}$ & District & SIFC & $\mathbf{R}$ \\
\hline st. Warszawa & 0.5176 & 1 & wałbrzyski & 0.3435 & 35 & bartoszycki & 0.2477 & 348 \\
\hline Sopot & 0.4951 & 2 & tatrzański & 0.3424 & 36 & wielicki & 0.2473 & 349 \\
\hline Świnoujście & 0.4634 & 3 & Piotrków Trybunalski & 0.3405 & 37 & dąbrowski & 0.2471 & 350 \\
\hline polkowicki & 0.4557 & 4 & Piekary Śląskie & 0.3401 & 38 & sandomierski & 0.2471 & 351 \\
\hline Gliwice & 0.4446 & 5 & Grudziądz & 0.3395 & 39 & kielecki & 0.2462 & 352 \\
\hline Rybnik & 0.4302 & 6 & piaseczyński & 0.3393 & 40 & śremski & 0.2460 & 353 \\
\hline Płock & 0.4270 & 7 & Nowy Sącz & 0.3386 & 41 & szczecinecki & 0.2460 & 354 \\
\hline Kraków & 0.4258 & 8 & kozienicki & 0.3363 & 42 & rawski & 0.2454 & 355 \\
\hline Opole & 0.4108 & 9 & Szczecin & 0.3361 & 43 & sejneński & 0.2445 & 356 \\
\hline Tychy & 0.4080 & 10 & nowomiejski & 0.3353 & 44 & poddębicki & 0.2429 & 357 \\
\hline Wrocław & 0.4067 & 11 & kartuski & 0.3342 & 45 & łobeski & 0.2422 & 358 \\
\hline łosicki & 0.3980 & 12 & Ruda Śląska & 0.3341 & 46 & ząbkowicki & 0.2421 & 359 \\
\hline Krosno & 0.3938 & 13 & lubiński & 0.3340 & 47 & tarnowski & 0.2412 & 360 \\
\hline Białystok & 0.3904 & 14 & mielecki & 0.3303 & 48 & elbląski & 0.2406 & 361 \\
\hline Bielsko-Biała & 0.3882 & 15 & janowski & 0.3292 & 49 & tomaszowski & 0.2404 & 362 \\
\hline Katowice & 0.3789 & 16 & Ostrołęka & 0.3281 & 50 & żarski & 0.2398 & 363 \\
\hline pruszkowski & 0.3785 & 17 & $\ldots$ & & & pułtuski & 0.2398 & 364 \\
\hline Poznań & 0.3777 & 18 & sokołowski & 0.2520 & 331 & mragowski & 0.2395 & 365 \\
\hline warszawski zach. & 0.3761 & 19 & piski & 0.2514 & 332 & żagański & 0.2335 & 366 \\
\hline Gdańsk & 0.3728 & 20 & zamojski & 0.2514 & 333 & Elblag & 0.2326 & 367 \\
\hline Zamość & 0.3724 & 21 & płocki & 0.2508 & 334 & proszowicki & 0.2322 & 368 \\
\hline Rzeszów & 0.3689 & 22 & kraśnicki & 0.2501 & 335 & miechowski & 0.2322 & 369 \\
\hline Tarnów & 0.3680 & 23 & sierpecki & 0.2499 & 336 & częstochowski & 0.2307 & 370 \\
\hline bełchatowski & 0.3643 & 24 & brzeziński & 0.2497 & 337 & jędrzejowski & 0.2275 & 371 \\
\hline Lublin & 0.3635 & 25 & szydłowiecki & 0.2496 & 338 & choszczeński & 0.2249 & 372 \\
\hline Konin & 0.3591 & 26 & wołowski & 0.2496 & 339 & kazimierski & 0.2222 & 373 \\
\hline Kalisz & 0.3586 & 27 & sulęciński & 0.2495 & 340 & człuchowski & 0.2199 & 374 \\
\hline Olsztyn & 0.3567 & 28 & Świętochłowice & 0.2494 & 341 & brzeski & 0.2096 & 375 \\
\hline Zielona Góra & 0.3557 & 29 & gryficki & 0.2489 & 342 & pyrzycki & 0.2090 & 376 \\
\hline pajęczański & 0.3535 & 30 & goleniowski & 0.2488 & 343 & myślenicki & 0.2062 & 377 \\
\hline Chorzów & 0.3511 & 31 & przasnyski & 0.2487 & 344 & kluczborski & 0.2028 & 378 \\
\hline Gdynia & 0.3469 & 32 & ostródzki & 0.2479 & 345 & milicki & 0.1729 & 379 \\
\hline Suwałki & 0.3461 & 33 & nakielski & 0.2479 & 346 & skarżyski & 0.1475 & 380 \\
\hline Dąbrowa Górnicza & 0.3446 & 34 & lubelski & 0.2478 & 347 & & & \\
\hline
\end{tabular}

Notes: SIFC—-taxonomic index of financial capacity at district level. 


\section{References}

1. Ministerstwo Administracji i Cyfryzacji. Długookresowa Strategia Rozwoju Kraju—Polska 2030. Trzecia Fala Nowoczesności; Ministerstwo Administracji i Cyfryzacji: Warszawa, Poland, 2013.

2. Czapiński, J.; Panek, T. Diagnoza Społeczna 2015 Warunki i Jakość Życia Polaków; Rada Monitoringu Społecznego: Warszawa, Poland, 2015.

3. OECD. How's Life? 2015: Measuring Well-Being; OECD Publishing: Paris, France, 2015. [CrossRef]

4. European Commision. Living Conditions in the European Union. Report. Available online: http://ec.europa. eu/commfrontoffice/publicopinion/archives/eb/eb81/eb81_vie_en.pdf (accessed on 25 September 2019).

5. Local Data Bank. Central Statistical Office. Available online: https://bdl.stat.gov.pl/BDL/start (accessed on 3 October 2019).

6. Słaby, T. Poziom i jakość życia. In Statystyka Społeczna; Panek, T., Ed.; PWE: Warszawa, Poland, 2007; pp. 99-130.

7. Max-Neef, M.A. Human Scale Development. Conception, Application and Further Reflections; The Apex Press: New York, NY, USA; London, UK, 1991.

8. Murray, M.; Pauw, C.; Holm, D. The House as a Satisfier for Human Needs: A Framework for Analysis, Impact Measurement and Design. In Proceedings of the XXXIII IAHS World Congress on Housing Transforming Housing Environments through Design, Pretoria, South Africa, 27-30 September 2005.

9. Ding, H.; Jiang, T.; Riloff, E. Why is an Event Affective? Classifying Affective Events based on Human Needs. In Proceedings of the Workshops at the Thirty-Second AAAI Conference on Artificial Intelligence, New Orleans, LA, USA, 2-7 February 2018; pp. 8-15.

10. Zienkowski, L. Poziom życia. In Metody Mierzenia i Oceny; PWE: Warszawa, Poland, 1979.

11. Zeliaś, A. Poziom Życia w Polsce i Krajach Unii Europejskie; Wydawnictwo Ekonomiczne: Warszawa, Poland, 2004.

12. Bywalec, C.; Rudnicki, L. Podstawy Teorii i Metodyki Badania Konsumpcji; Akadamia Ekonomiczna w Krakowie: Kraków, Poland, 1992.

13. Piasny, J. Problem Jakości Życia Ludności Oraz Źródła i Mierniki ich Określania; RPEiS: Poznań, Poland, 1993.

14. Berbeka, J. Poziom Życia Ludności a Wzrost Gospodarczy w Krajach Unii Europejskiej; Wydawnictwo Akademii Ekonomicznej w Krakowie: Kraków, Poland, 2006.

15. Hansen, M.E.; Grubb, F. Anthropometric Versus Income Measures of the Standard of Living: Issues of Theoretical Consistency; Department of Economics, American Univeristy: Washington, DC, USA, 2002; Available online: http://www.humanics-es.com/anthro11-13-02.pdf (accessed on 25 September 2019).

16. Kalinowki, S. Poziom Życia Ludności Wiejskiej o Niepewnych Dochodach; Wydawnictwo Naukowe PWN: Warszawa, Poland, 2015.

17. Mourad, M.; Perez, A.; Richardson, C. Digital Inclusion Social Impact Evaluation; Final Report; One Global Economy: Washington, DC, USA, 2014.

18. OSCE/ODIHR. Good Practices in Migrant Integration: TRAINEE'S MANUAL; OSCE Office for Democratic Institutions and Human Rights (ODIHR): Warsaw, Poland, 2018.

19. McGregor, S.L.T.; Goldsmith, E.B. Expanding our understanding of quality of life, standard of living, and well-being. J. Fam. Consum. Sci. 1998, 90, 2-22.

20. Tarno, J.P.; Sieniuć, M.; Sulimierki, J.; Wyporska, J. Samorząd Terytorialny w Polsce; Wydawnictwo Prawnicze LexisNexis: Warszawa, Poland, 2002.

21. Dylewski, M.; Filipiak, B.; Gorzałczyńska-Koczkodaj, M. Finanse Samorządowe, Narzędzia, Decyzje, Procesy, Wyd; Naukowe PWN: Warszawa, Poland, 2006.

22. Ziółkowska, W. Finanse Publiczne. Teoria i Zastosowania, Wyd; Wyższa Szkoła Bankowa: Poznań, Poland, 2002.

23. Ustawa z Dnia 8 Marca 1990 r. o Samorządzie Gminnym (Dz.U. 1990 Nr 16 poz. 95). Available online: http://prawo.sejm.gov.pl/isap.nsf/DocDetails.xsp?id=WDU19900160095 (accessed on 2 October 2019).

24. Ustawa z Dnia 5 Czerwca 1998 r. o Samorządzie Powiatowym (Dz.U. 1998 Nr 91 poz. 578). Available online: http://prawo.sejm.gov.pl/isap.nsf/DocDetails.xsp?id=WDU19980910578 (accessed on 2 October 2019).

25. Ustawa z Dnia 5 Czerwca 1998 r. o Samorządzie Województwa (Dz.U. 1998 Nr 91 poz. 576). Available online: http://prawo.sejm.gov.pl/isap.nsf/DocDetails.xsp?id=WDU19980910576 (accessed on 2 October 2019).

26. Parysek, J.J. Podstawy Gospodarki Lokalnej; Wydawnictwo Naukowe UAM: Poznań, Poland, 2001. 
27. Konstytucja Rzeczypospolitej Polskiej z Dnia 2 Kwietnia 1997 r. (Dz.U. 1997 nr 78 poz. 483). Available online: http://prawo.sejm.gov.pl/isap.nsf/DocDetails.xsp?id=WDU19970780483 (accessed on 2 October 2019).

28. Tetera, M. Zadania samorzadu terytorialnego. Materialne podstawy i prawne formy realizacji. In Samorzad Terytorialny. Ustrój i Gospodarka; Niewiadomski, Z., Ed.; Oficyna Wydawnicza Branta: Bydgoszcz-Warszawa, Poland, 2001; pp. 53-88.

29. Owsiak, S. Budżet Władz Lokalnych; PWE: Warszawa, Poland, 2002.

30. Ustawa z Dnia 27 Sierpnia 2009 r. o Finansach Publicznych (Dz.U. 2009 Nr 157 poz. 1240). Available online: http://prawo.sejm.gov.pl/isap.nsf/DocDetails.xsp?id=WDU20091571240 (accessed on 2 October 2019).

31. Malinowski, M. Możliwości finansowe samorządu terytorialnego a poziom życia mieszkańców Polski Wschodniej-Wykorzystanie analizy kanonicznej. Studia Ekonomiczne Zeszyty Naukowe Uniwersytetu Ekonomicznego w Katowicach 2016, 303, 203-219.

32. Ustawa z Dnia 13 Listopada 2003 r. o Dochodach Jednostek Samorządu Terytorialnego (Dz.U. 2003 Nr 203 poz. 1966). Available online: http://prawo.sejm.gov.pl/isap.nsf/DocDetails.xsp?id=WDU20032031966 (accessed on 2 October 2019).

33. Warzecha, K. Poziom życia ludności polski i pozostałych krajów Unii Europejskiej-Analiza taksonomiczna. In Gospodarka Polska po 20 Latach Transformacji, Osiagnięcia, Problemy i Wyzwania; Pongsy-Kania, S., Ed.; Wydawnictwo IWiI: Warszawa, Poland, 2009.

34. Majka, A. Taksonomiczna analiza zróżnicowania poziomu życia w Polsce. Prace Naukowe Uniwersytetu Ekonomicznego we Wrocławiu 2015, 407, 354-363. [CrossRef]

35. Janusz, M. Poziom Życia i Jego Przestrzenne Zróżnicowanie w Województwie Warmińsko-Mazurskim. Econ. Manag. 2014, 4, 169-184. [CrossRef]

36. Zhou, L.; Shi, C.; Luo, L. Application of AHP Method and TOPSIS Method in Comprehensive Economic Strength Evaluation of Major Cities in Guizhou Province. DEStech Trans. Comput. Sci. Eng. 2018, 687-694. [CrossRef]

37. Łapczyński, M. Wpływ Aktywności Mieszkańców na Poziom Życia w Gminach Woj. Małopolskiego. Available online: https://media.statsoft.pl/_old_dnn/downloads/wplyw_aktywnosci.pdf (accessed on 10 November 2019).

38. Hlepas, N. Quality of Life and Local Governance; WP5/21 Search Working Paper; SEARCH: Barcelona, Spain, 2013.

39. Oleszko-Kurzyna, B. Jakość życia a procesy zarządzania rozwojem gmin wiejskich. Studia Ekonomiczne/ Uniwersytet Ekonomiczny w Katowicach 2014, 179, 85-93.

40. Cárcaba, A.; González, E.; Ventura, J.; Arrondo-García, R. How Does Good Governance Relate to Quality of Life? Sustainability 2017, 9, 631. [CrossRef]

41. Dynowska, J.; Rudowicz, E. Oddziaływanie samorządu terytorialnego na rozwój lokalny gmin. Acta Scientiarum Polonorum. Oeconomia 2007, 6, 27-35.

42. Pondel, H. Rola samorządu gminnego w stymulowaniu rozwoju obszarów wiejskich. Studia BAS 2017, 1, 109-131.

43. Korol, J.; Szczuciński, P. Ekonometryczne Modelowanie Procesów Gospodarki Regionalnej Opartej na Wiedzy; Wydawnictwo Adam Marszałek: Torun, Poland, 2009.

44. Balicki, A. Statystyczna Analiza Wielowymiarowa i Jej Zastosowanie Społeczno-Ekonomiczne; Wydawnictwo Uniwersytetu Gdańskiego: Gdańsk, Poland, 2009.

45. Zeliaś, A. Metody Statystyczne; PWE: Warszawa, Poland, 2000.

46. Młodak, A. Analiza Taksonomiczna w Statystyce Regionalnej; Difin: Warszawa, Poland, 2006.

47. Panek, T.; Zwierzchowski, J. Statystyczne Metody Wielowymiarowej Analizy Porównawczej: Teoria i Zastosowania; Oficyna Wydawnicza SHG: Warszawa, Poland, 2013.

48. Hwang, C.L.; Yoon, K. Multiple Attribute Decision Making: Methods and Applications; Springer: Berlin/Heidelberg, Germany; New York, NY, USA, 1981.

49. Mukaka, M.M. Statistics corner: A guide to appropriate use of correlation coefficient in medical research. Malawi Med. J. 2012, 24, 69-71. [PubMed]

50. Suchecki, B. Ekonometria Przestrzenna. Metody i Modele Analizy Danych Przestrzennych; Wydawnictwo C.H. Beck: Warszawa, Poland, 2010.

51. Kopczewska, K. Ekonometria i Statystyka Przestrzenna z Wykorzystaniem Programu R-Cran; CeDeWu: Warszawa, Poland, 2007. 
52. Diermeier, M.; Goecke, H. Usually an Economic Driving Force. Available online: https: //www.iwkoeln.de/presse/iw-nachrichten/beitrag/matthias-diermeier-henry-goecke-capital-citiesusually-an-economic-driving-force-366303.html (accessed on 12 November 2019).

53. Fingar, C. fDi's European Cities and Regions of the Future 2018/19; The Financial Times Ltd.: London, UK, 2018.

54. Guziejewska, B. Zrównoważony Rozwój Miast. Polityka i Finanse; Wydawnictwo Uniwersytetu Łódzkiego: Łódź, Poland, 2015.

55. Zeliaś, A. Ekonometria Przestrzenna; Polskie Wydawnictwo Ekonomiczne: Warszawa, Poland, 1991.

56. Kossowski, T. Teoretyczne aspekty modelowania przestrzennego w badaniach regionalnych. Rozwój Regionalny i Polityka Regionalna 2010, 12, 9-26.

57. Bivand, R. Autokorelacja przestrzenna a metody analizy statystycznej w geografii. In Analiza Regresji $w$ Geografii; Chojnicki, Z., Ed.; PWN: Warszawa-Poznań, Poland, 1980; pp. 23-38.

58. Anselin, L. Spatial Econometrics. In A Companion to Theoretical Econometrics; Baltagi, B.H., Ed.; Blackwell Publishing Ltd.: Oxford, UK, 2003; pp. 310-330.

59. LeSage, J.P.; Pace, R.K. Introduction to Spatial Econometrics; Taylor \& Francis Group: Boca Raton, FL, USA, 2009.

60. Kołodziejczak, A.; Kossowski, T. Wykorzystanie metody autokorelacji przestrzennej do analizy ubóstwa na obszarach wiejskich. Wiadomości Statystyczne 2016, 10, 22-32.

61. Lechman, E. Analiza Zależności Przestrzennych Między Wdrożeniem ICT a Wzrostem Gospodarczym na Przykładzie Krajów Ameryki ŁACIŃSKIEJ w Latach 2000-2013; University of Technology: Gdansk, Poland, 2015. [CrossRef]

62. Pander, W.; Rauzer, A.; Stawicki, M.; Sycz, P.; Wojnicka-Sycz, E. Wyznaczanie, Monitoring i Ewaluacja Inteligentnych Specjalizacji; Wydawnictwo Maciej Stawicki: Warszawa, Poland, 2014.

(C) 2020 by the authors. Licensee MDPI, Basel, Switzerland. This article is an open access article distributed under the terms and conditions of the Creative Commons Attribution (CC BY) license (http://creativecommons.org/licenses/by/4.0/). 